University of Nebraska - Lincoln

DigitalCommons@University of Nebraska - Lincoln

Faculty Publications in Food Science and Technology

Food Science and Technology Department

2006

Tannerella forsythia, a periodontal pathogen entering the genomic

era

Anne C.R. Tanner

Jacques Izard

Follow this and additional works at: https://digitalcommons.unl.edu/foodsciefacpub

Part of the Biological Phenomena, Cell Phenomena, and Immunity Commons, Food Science

Commons, Genomics Commons, Immunology and Infectious Disease Commons, Medical Microbiology

Commons, and the Periodontics and Periodontology Commons

This Article is brought to you for free and open access by the Food Science and Technology Department at DigitalCommons@University of Nebraska - Lincoln. It has been accepted for inclusion in Faculty Publications in Food Science and Technology by an authorized administrator of DigitalCommons@University of Nebraska Lincoln. 


\title{
Tannerella forsythia, a periodontal pathogen entering the genomic era
}

\author{
Anne C. R. Tanner \& Jacques Izard
}

Several questions need to be addressed to evaluate whether Tannerella forsythia is to be considered a periodontal pathogen. T. forsythia has been detected in periodontal health and disease, so could it be a pathogen? The species was not detected in many studies despite finding other putative pathogens, so could it be important in pathogenicity? The challenges of working with T. forsythia include its fastidious and anaerobic growth requirements for cultural detection. Thus, studies associating $T$. forsythia with periodontal and other oral infections have used noncultural approaches (immunoassays and DNA-based assays) in addition to cultural approaches. We feel the timing of this review represents an interesting transition period in our understanding of the relationships of species with infection. Information from the recently released full genome sequence data of T. forsythia will provide new approaches and tools that can be directed to assess pathogenicity. Furthermore, molecular assessment of gene expression will provide a new understanding of the pathogenical potential of the species, and its effect on the host.

T. forsythia, was described in reviews focusing on periodontal pathogens associated with herpesvirus detection (200), species for which genome projects were underway (41), members of polybacterial periodontal pathogenic consortium (91), and participants in periodontal microbial ecology (202). We will describe the history, taxonomy, and

Published in Periodontology 2000, vol 42 (2006), pp 88-113.

doi:10.1111/j.1600-0757.2006.00184.x

Copyright (C) 2006 Anne C. R. Tanner \& Jacques Izard; journal compilation (C) 2006 Blackwell

Munksgaard. Used by permission. 
characteristics of T. forsythia, and related species or phylotypes in the genus Tannerella. To assess the pathogenic potential of T. forsythia, we first describe species associations with periodontal and other infections, including animal models, as has been the traditional approach arising from Koch's postulates (203). Criteria for pathogenicity were expanded to incorporate sequence- derived information (58), and again more recently to include molecular signatures of pathogens and disease (170). We used sequence and genome-derived information, in addition to biofilm, pathogenic mediators, and host responses, to further explore the pathogenic potential of T. forsythia.

\section{History and taxonomy}

T. forsythia was first isolated at The Forsyth Institute from subjects with progressing advanced periodontitis in the mid-1970s and was described as "fusiform Bacteroides" by Tanner et al. (225). Around the same time, T. forsythia was isolated as one of the Bacteroides group from the extensive cultural studies of periodontal infections by Moore and Holdeman- Moore at the Anaerobe Laboratory of the Virginia Polytechnic Institute (VPI). The species was subsequently detected by culture from oral samples at the Forsyth and VPI laboratories from progressing periodontitis $(43,153,229)$, endodontic infections (232), gingivitis and early periodontitis $(151,221)$, refractory periodontitis (81), and peri-implantitis (223).

T. forsythia was initially a taxonomic enigma because it did not resemble described species of oral or enteric gram-negative anaerobic rods, particularly in its cell morphology and slow and fastidious growth requirements. As a gram-negative anaerobic rod with tapered ends, it was described as "fusiform Bacteroides" in our cultural report of progressing advanced periodontitis (225). Sufficient cells for characterization were obtained by enhancing growth by culturing T. forsythia on blood agar adjacent to Fusobacterium nucleatum cells. Growth stimulation by a number of species was observed during an extensive search to improve growth of the species (42). The moles percent (mol\%) DNA content was determined to be around $46 \%$, and is currently reported at $46.8 \%$ based on genome sequence (http://www.oralgen.lanl.gov). Strains collected from subgingival and endodontic lesions showed over 75-100\% DNA 
homology with each other. DNA homology with enteric Bacteroides species was for 0-31\% Bacteroides fragilis, 0-28\% for Bacteroides thetaiotaomicron, 0-20\% for Bacteroides vulgatus, and 0-48\% for Bacteroides distasonis. DNA homology with other oral "Bacteroides" (now Prevotella) species, was 0-30\% for Prevotella oris, 5-14\% for Prevotella oralis, and 11-17\% for Prevotella buccae.

The phylogeny of oral Bacteroides species in the Cytophaga-Flavobacterium-Bacteroides family was reorganized after Bacteroides forsythus was described. Most oral "Bacteroides" species were reclassified to either Porphyromonas (188) or Prevotella (189), conserving the genus Bacteroides for the $B$. fragilis-like enteric species. Several species including B. forsythus and Bacteroides distasonis, did not belong in Porphyromonas, Prevotella or Bacteroides. These relationships were clarified in the phylogenetic studies comparing 16S rRNA sequence data by Paster et al. (168). These data confirmed the separation of oral gram-negative anaerobic rod species from enteric species. In the $16 \mathrm{~S}$ rRNA sequence analysis (168), B. forsythus grouped with B. distasonis, consistent with the previous DNA homology data, but these two species clustered outside the Prevotella and Bacteroides groups. B. forsythus clustered most closely with Porphyromonas species, but not closely enough to be considered as Porphyromonas. The 16S rRNA phylogenetic analysis supporting reclassification of $B$. forsythus to the genus Tannerella further expanded the range of Porphyromonas, Bacteroides, and Prevotella species examined (179). The genus name was chosen for Anne Tanner who described the species as B. forsythus in 1986 (232). The Sakamoto 16S rRNA phylogenetic analysis confirmed the separation of T. forsythia, B. distasonis, and Bacteroides merdae (the latter both enteric species) from the other genera (179). The species was first formally reclassified to Tannerella forsythensis, then reclassified to T. forsythia (143) following a proposal to change the specific epithet (Brian J. Tindall 2005, personal communication). This specific epithet change was based on The Forsyth Institute being named for the Forsyth brothers, James, Thomas, and John, along with their sister Mary who founded the institution in 1910 as The Forsyth Dental Infirmary for Children. The specific epithet honors these benefactors.

The current taxonomic position of the genus Tannerella and related genera within the phylum Bacteroidetes based on 16S rRNA phylogenetic analysis is illustrated in Fig. 1. In particular, this figure illustrates the 
(\% Difference)

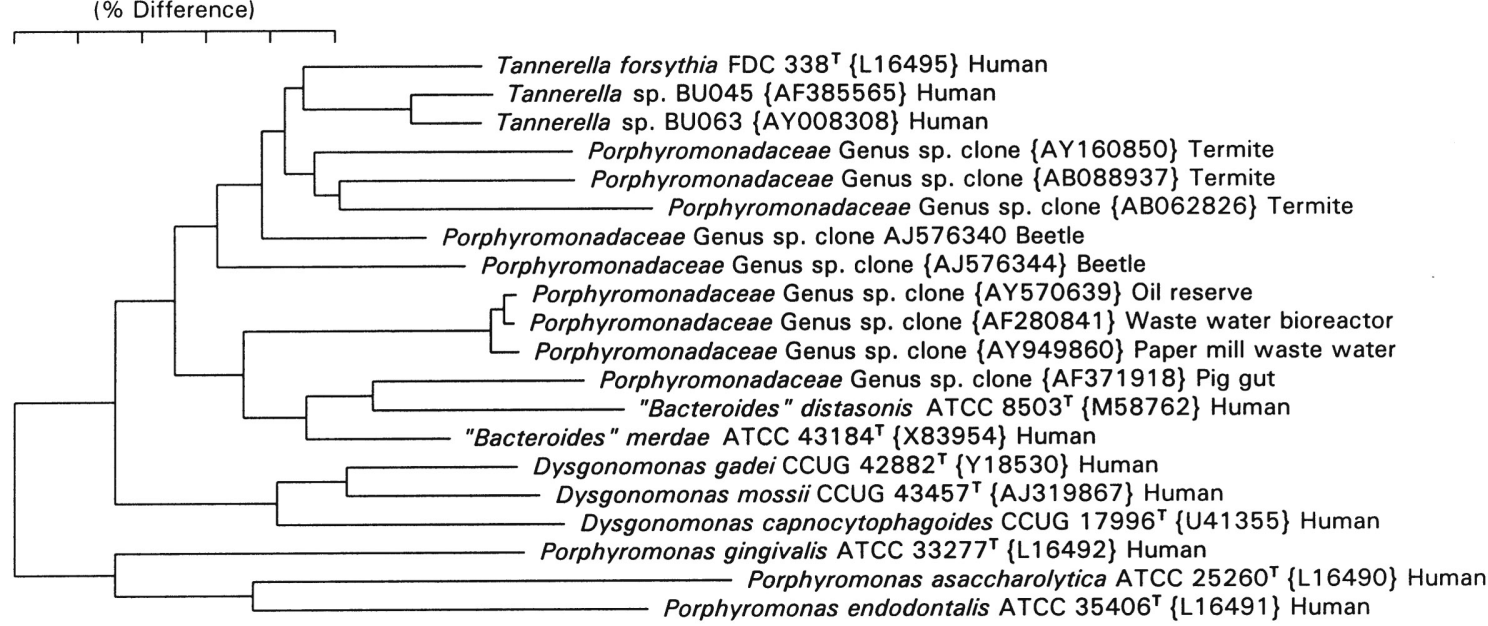

Fig. 1. Phylogenetic tree of the genus Tannerella and other genera in the phylum Bacteroidetes. The tree was constructed from aligned sequences using the neighbor-joining method. The naming scheme is as follows: (1) for cultivated species the official or provisional name was used; for not yet cultivated taxa the designation was to the closest genus or family (e.g. Porphyromonadaceae); (2) the 16S rRNA gene accession number is in curly brackets; and (3) original sample/isolate source. The bar denotes a $5 \%$ difference in sequence measured by summing the lengths of the horizontal lines between taxa.

phylogenetic relationship between T. forsythia, B. distasonis, and B. merdae. Three Porphyromonas species are also included to illustrate their relationship with Tannerella.

\section{T. forsythia from non-human hosts and other Tannerella phylotypes}

Strains of $T$. forsythia have been isolated from the subgingival plaque of monkeys, and in humans from cat and dog bite wounds (Fig. 2). The $T$. forsythia strains isolated from monkeys were quite similar to the $T$. forsythia strains from humans both biochemically and in their requirement for $\mathrm{N}$-acetylmuramic acid (12). Comparison of human and monkey isolates with those from cat and dog bite wounds indicated that dog and cat bite isolates differed in their lack of requirement for $N$-acetylmuramic acid for growth, and catalase activity. In addition, cat and dog bite isolates differed by their phenylalanine aminopeptidase activity compared to the monkey isolates (94). Previous phylogenetic analysis of $16 \mathrm{~S}$ rRNA gene sequences indicated that the monkey isolates were more similar 
(\% Difference)

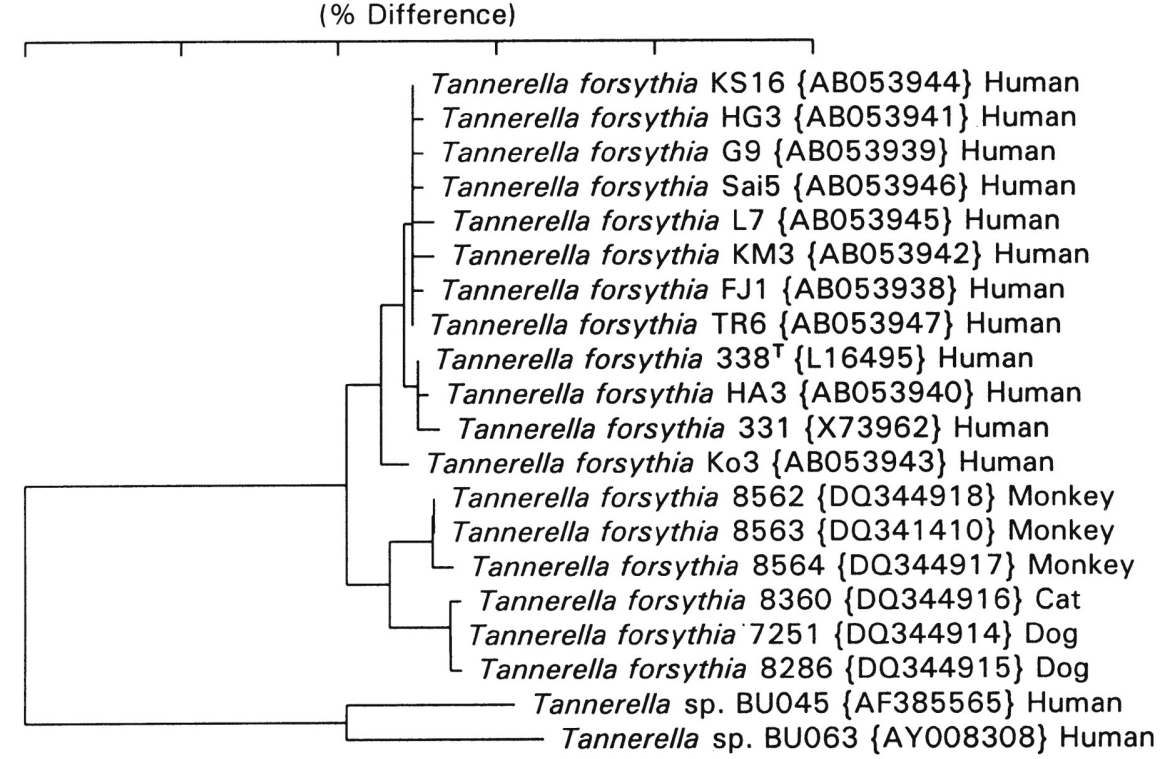

Fig. 2. Tannerella forsythia $16 \mathrm{~S}$ rRNA distribution based on sequences deposited in GenBank. The tree was constructed from aligned sequences using the neighbor-joining method. The naming scheme is as follow: (1) official or provisional names; (2) the 16S rRNA gene accession number in curly brackets; and (3) original sample/isolate source. The bar denotes a $5 \%$ difference in sequence as measured by summing the lengths of the horizontal lines between taxa. The 16S rRNA gene sequences from monkey oral isolate (12), as well as dog and cat bite (94) have been deposited in GenBank for the purpose of this review under the accession numbers DQ341410, and DQ344914-DQ344918.

to the type strain from human, than to the dog and cat isolates (94). The new phylogenetic analysis in Fig. 2 illustrates that the monkey isolates and strains from dog and cat bite wounds are closely related to human isolates of T. forsythia and all belong in the same species.

Three distinct Tannerella phylotypes have been recognized from human subgingival sites. In addition to T. forsythia, two other phylotypes, BU063 and BU045, were identified from a clone library (167). The phylogenetic trees of Fig 1 and 2 illustrate that the oral clones BU045 and BU063 fall within the genus Tannerella but not within the T. forsythia species. There are currently no cultured isolates with sequences similar to those of the BU045 and BU063 clones. Sequence-based polymerase chain reaction methods indicated that T. forsythia was detected more frequently from periodontitis, relative to the Tannerella BU063 clone phylotype which was detected more frequently from periodontal health 
(132). In the latter study, DNA was first amplified from plaque samples using universal (broad range) primers for regions in $16 \mathrm{~S}$ and $23 \mathrm{~S}$ genes. A second, nested, polymerase chain reaction amplification included a sequence in the 23S rDNA gene, thus amplifying the intergenic spacer region. This analysis yielded product/amplicons at different molecular weights, corresponding to the different phylotypes (132).

Examination of $16 \mathrm{~S}$ rRNA sequence data deposited in GenBank indicates that several other Tannerella organisms have been detected in the soil and from the gut of insects (Fig. 1). These microorganisms emerged from polymerase chain reaction-cloning sequencing analyses, and only clone sequences are available, not cultured isolates. These phylotypes were detected in the guts of soil-feeding termites (186), scarab beetle larvae (47), and wood-eating termites (194). These Tannerella species may co-exist with Treponema species that have recently been cultured with unusual and fastidious growth requirements from termite guts (70). The environment for these insect-isolated Tannerella and Treponema organisms is clearly different from that of the human oral cavity, with markedly different nutrient sources. Detection of phylotypes of genera in oral and environmental samples has also been reported for uncultivated TM7 $(96,167)$, Obsidian pool $(96,167)$, and Archea (131). One might speculate that soil organisms were the original source for these fastidious species and that the growth requirements of Tannerella and uncultivated phylotypes may reflect the original source of the species.

\section{Characteristics of $T$. forsythia and identification in clinical samples}

\section{Characteristics of isolates}

The growth of $T$. forsythia is stimulated by $N$-acetylmuramic acid (260). The shape of T. forsythia cells and colonies varies depending on the growth conditions. Cells of cultures grown on agar media without $\mathrm{Nac}-$ etylmuramic acid are large, filamentous, and pleomorphic, with tapered (fusiform) ends, also with spheroids. As described above, the growth requirement for $\mathrm{N}$-acetylmuramic acid was observed for strains isolated from dental plaque from humans and monkeys (Macaca fascicularis) (12), but not for the T. forsythia strains isolated from dog and cat bite 


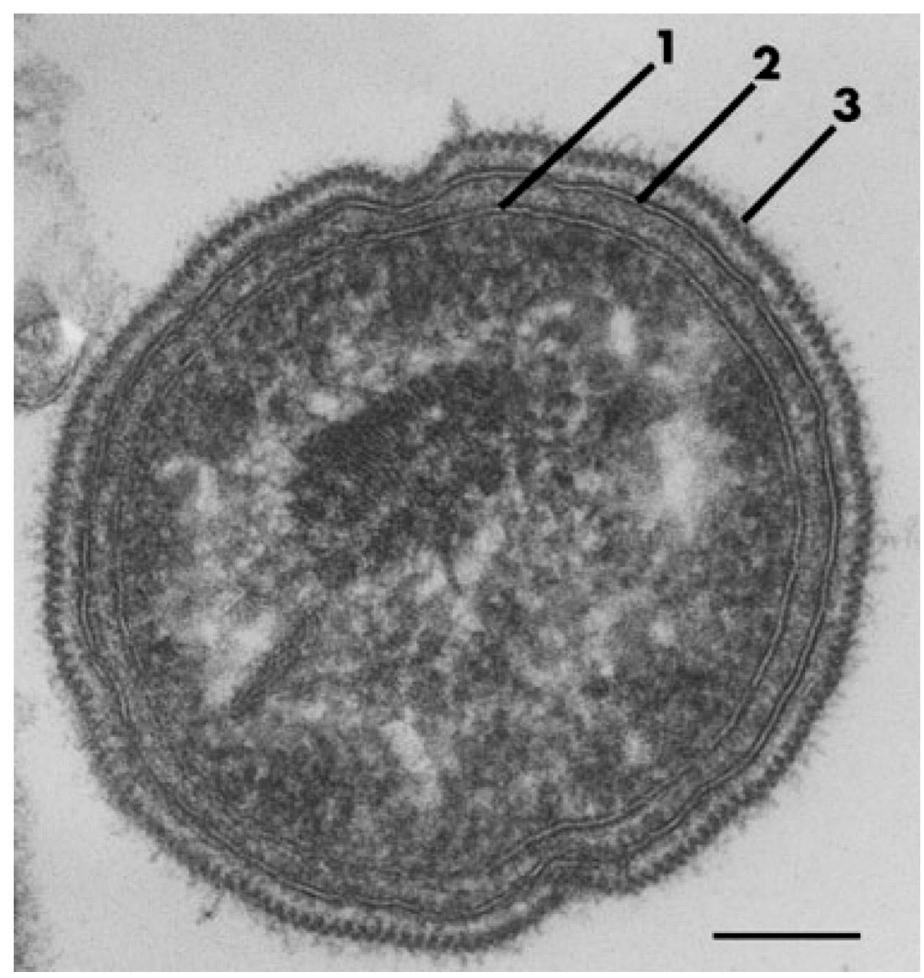

Fig. 3. Cell cross-section of Tannerella forsythia ATCC 43037. The cells were fixed in sodium cacodylate buffer, dehydrated, and embedded in Epon. Sections were mounted on grids and stained with uranyl acetate and lead citrate (232). (1) Inner-membrane, (2) Outer-membrane, and (3) Distinctive outer layer. Scale bar $=0.1 \mu \mathrm{m}$. Reprinted with the permission of the International Journal of Systemic and Evolutionary Microbiology.

wounds (94). T. forsythia has a distinctive ultrastructure (Fig. 3). Below a distinctive outer layer ( $\mathrm{S}$ layer) there is an inner membrane, and an outer membrane (232). Colonies are tiny and opaque. Colony morphology changes in the presence of either $N$-acetylmuramic acid or a growthstimulating species, for example $F$. nucleatum (232). Colonies become pale pink and speckled, circular, entire, slightly convex, and may have a depressed center (donut-shaped). In the presence of $N$-acetylmuramic acid, cells become regularly shaped, short, gram-negative rods (12).

Biochemically $T$. forsythia can be deceptively inert when tested using slight broth growth achieved in the absence of $\mathrm{N}$-acetylmuramic acid. When cells are harvested from agar the biochemical reactivity of the species becomes apparent. Biochemical reactivity from resting cell tests (enzyme substrate tests) has been performed on commercially available strips $(179,230)$ and from chromogenic reagents (145). T. forsythia 
has the ability to metabolize a range of substrates and, in common with many enteric Bacteroides species, to hydrolyze esculin. In contrast to the enteric species, however, T. forsythia is not resistant to bile, thus it does not grow on the routine Bacteroides medium for enteric species, Bile Esculin Agar (179). Because of slight broth growth of T. forsythia when originally described, characterization included whole cell protein profiles on sodium dodecyl sulfate-polyacrylamide gel electrophoresis, which for isolates of human origin demonstrated a signature double band greater than $200 \mathrm{kDA}$ (232). All strains tested, except one monkey isolate (94), also demonstrated these protein bands, which have been characterized as S-layer bands (90).

Cultural isolation of periodontal species, particularly the nutritionally fastidious pathogens of the "red complex" (205), requires more than including all the various growth-stimulating factors in a single medium. Isolation and cultivation of oral treponemes, including Treponema denticola, is routinely performed in specialized media $(104,241)$, which is commercially available (Anaerobe Systems, Morgan Hill, CA). While Porphyromonas gingivalis and T. forsythia will grow on media supplemented with vitamin $\mathrm{K}$ (menadione) for $P$. gingivalis, and $N$-acetylmuramic acid for T. forsythia, each species is inhibited by the growth requirement of the other, so compromising primary isolation (226). Both T. forsythia and P. gingivalis are anaerobes but it also has been suggested that they may, similar to $B$. fragilis (9), be able to grow in the presence of low levels of oxygen. This has been demonstrated for P. gingivalis (36). On primary isolation from oral samples, however, strict anaerobiosis favors isolation of T. forsythia and other subgingival anaerobes (39).

\section{Antibiotic sensitivity}

T. forsythia is generally sensitive to antibiotics that are active against anaerobes. Most active antibiotics were amoxicillin with clavulanate (100\%), ampicillin (98\%), doxycycline (98\%), amoxocillin (96\%), tetracycline (90\%), and clindamycin (86\%) (126). Fairly active antibiotics were penicillin (70\%) and spiramycin (68\%) whereas poorly active antibiotics were erythromycin (54\%) and ciprofloxacin (46\%) (126). In addition, T. forsythia was found to be sensitive to metronidazole (216). Results from a study of Brazilian isolates provided similar observations 
to these studies (139). Sensitivity to tetracycline is consistent with the failure to detect T. forsythia-resistant strains after local tetracycline therapy (67). Resistance to penicillin can be mediated by the production of $\beta$-lactamase. Isolates of $T$. forsythia with $\beta$-lactamase activity were identified from two of 23 (8\%) untreated adult periodontitis subjects (11\% two of 19 total isolates) (246). Addition of clavulanic acid to amoxicillin overcomes $\beta$-lactamase inactivation of penicillin, as described in a recent review (253).

The genome sequence of T. forsythia ATCC 43037 (see below) includes a copy of tet(Q), a gene encoding the ribosome protection protein resulting in antibiotic resistance to tetracycline. This observation adds $T$. forsythia to the list of oral organisms with this mechanism of antibiotic resistance (251). Not all genomes from oral isolates encode for a ribosome protection protein, like tet(Q), or an efflux pump providing antibiotic resistance to the organism (251). In addition to tet(Q) genes, strains of $T$. forsythia contained erm(F) which codes for erythromycin resistance (244).

Other antibiotic, or antimicrobial formulations with activity against T. forsythia include flurithromycin (134), moxifloxacin (149), and fanopenem (148). T. forsythia is sensitive to several non-antibiotic, antibacterial approaches which are designed for topical or local administration. These include silver nitrate (210), and chlorin e6 conjugated to pentalysine-5K in conjunction with laser photodynamic therapy (172). Topical activity of chlorhexidine gluconate (PerioChip) against T. forsythia provided little suppression compared with scaling and root planing (28). Good activity in vitro was demonstrated using a different polymer-based vehicle (266).

\section{Identification from clinical samples}

A number of methods have been used to detect T. forsythia in clinical samples and host tissues. Detection methods included immunoassay and genetic/molecular assays. In this review we focus on methods used to identify $T$. forsythia in samples rather than providing a comprehensive review of microbiological identification methods, for which there are already some excellent reviews $(23,161,181,184,196,202)$. 


\section{Cultural identification}

Identification tests when using cultural analysis were simplified from the range of tests used to characterize the species for classification and taxonomy. Slots presented a scheme for rapid identification of P. gingivalis (then Bacteroides gingivalis) from culture (199) comprising colony pigmentation, lack of fluorescence by long-wave UV light, and negative lactose fermentation (MUG test). This was adapted to T. forsythia, which differs in colony morphology and positive lactose fermentation (MUG test). Other strain identification schemes incorporate characterization using, for example, chromogenic test strips from API, or fluorogenic enzyme substrate tests (145). Key tests include $\alpha$-glucosidase, $\beta$-glucosidase, sialidase, and negative indole in addition to positive trypsin-like activity (12). In a comparison of culture with a DNA-probe assay, definitive identification of $T$. forsythia was obtained by a combination of colony morphology, trypsin-like activity and sodium dodecyl sulfatepolyacrylamide gel electrophoresis for a specific identification (226).

The ability of T. forsythia to hydrolyze the trypsinlike benzyol-DL-arginine-2-naphthylamide, "BANA", has been incorporated in the test for periodontal pathogens pioneered by Loesche (136). Trypsin-like activity is shared by P. gingivalis and T. denticola of the Socransky "red complex" (205). Other subgingival species are also BANA-positive, but not as strongly as P. gingivalis, T. denticola, and T. forsythia, thus making this biochemical marker a test for the presence of these species. The BANA test in the U.S.A., or SK-013 test in Japan, was devised for rapid clinical detection of a periodontal pathogen-containing microbiota $(137,187)$.

\section{Immunological assays}

Antibody raised against T. forsythia cells and used for species identification, did not cross-react with P. gingivalis, Prevotella intermedia, or Prevotella melaninogenica (44). Antibody to T. forsythia was serologically distinct from other oral and clinical "Bacteroides" species (now Bacteroides, Porphyromonas, and Prevotella) (45). Lai et al. (125) demonstrated that polyclonal antibody to T. forsythia in an indirect immunofluorescence assay did not react with an extended range of oral gramnegative and gram-positive species. Monoclonal antibodies were also produced against $T$. forsythia that were strain and species specific and 
that did not react with other subgingival species (255). They were subsequently used in enzyme-linked immunosorbent assays and immunofluorescence assays (255). Immunoassays have been used extensively by several groups of investigators for rapid identification of T. forsythia in periodontal health and diseases (Table 1). Direct identification from clinical samples bypasses the challenges of species culture. Lai et al. in Philadelphia U.S.A. (125) used polyclonal antibody in an immunofluorescence assay, and demonstrated change in detection after therapy. Gmu“ r et al., in Zurich Switzerland, used specific monoclonal antibodies in immunofluorescence assays to evaluate associations of T. forsythia with periodontal health and disease (63-65). Zambon et al. incorporated immunofluorescence assay identification of $T$. forsythia to evaluate microbial sampling protocols (75) and in studies of risk indicators for periodontal disease $(72,73)$. Immunofluorescence assay to identify T. forsythia was also used in our comparison of rapid (chair-side) DNA probe identification with culture to clarify the status of culture-negative, probe-positive samples (226).

\section{Molecular identification}

Molecular methods for species identification in samples have evolved from DNA/DNA homology to sequence-based methods used in microbial taxonomy $(167,179,224,232)$. The diversity of the oral species based on molecular methods used the comprehensive polymerase chain reaction/cloning/ sequencing steps $(124,157,167,182)$. Rapid identification of $T$. forsythia using molecular methods may be broadly grouped into DNA probe and polymerase chain reaction methods, although several approaches incorporate both technologies.

\section{DNA probes}

DNA probe methods have been used in conjunction with culture or directly from oral samples. DNA probes have been made from whole genomic DNA, from species-specific cloned DNA fragments or oligonucleotide sequences. Whole genomic probes for T. forsythia showed minimal cross-reactivity with other species $(202,208)$. The colony-lift method used colonies from primary isolation plates that had been transferred (lifted) onto nylon membranes (74). Using primary isolation plates 


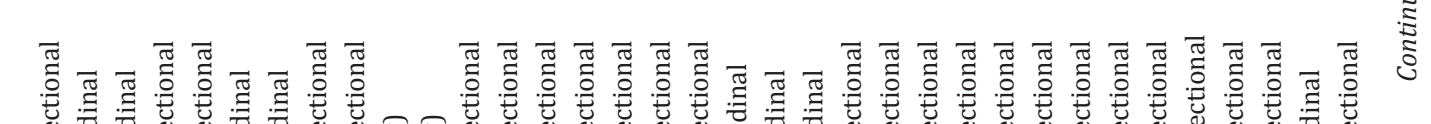
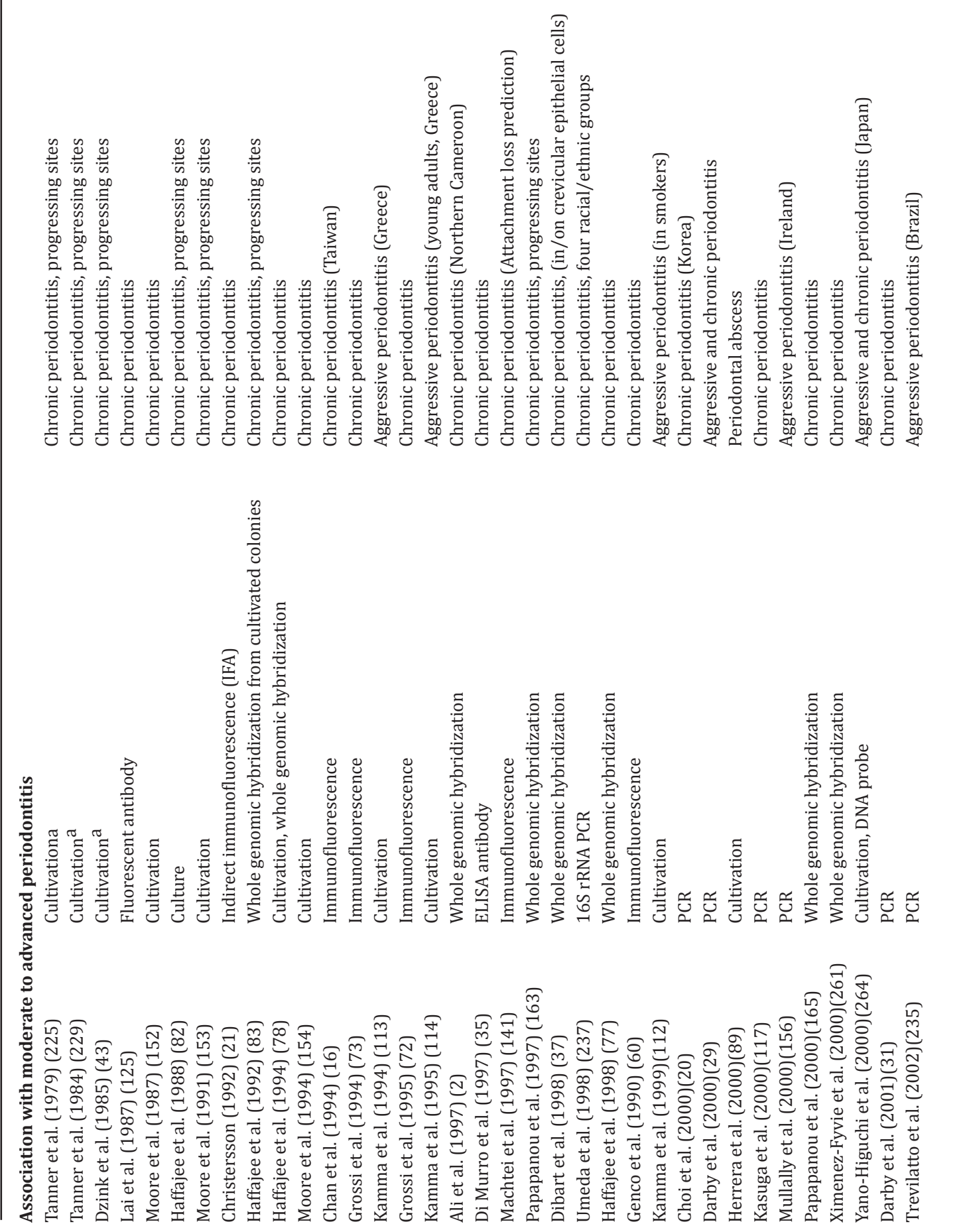

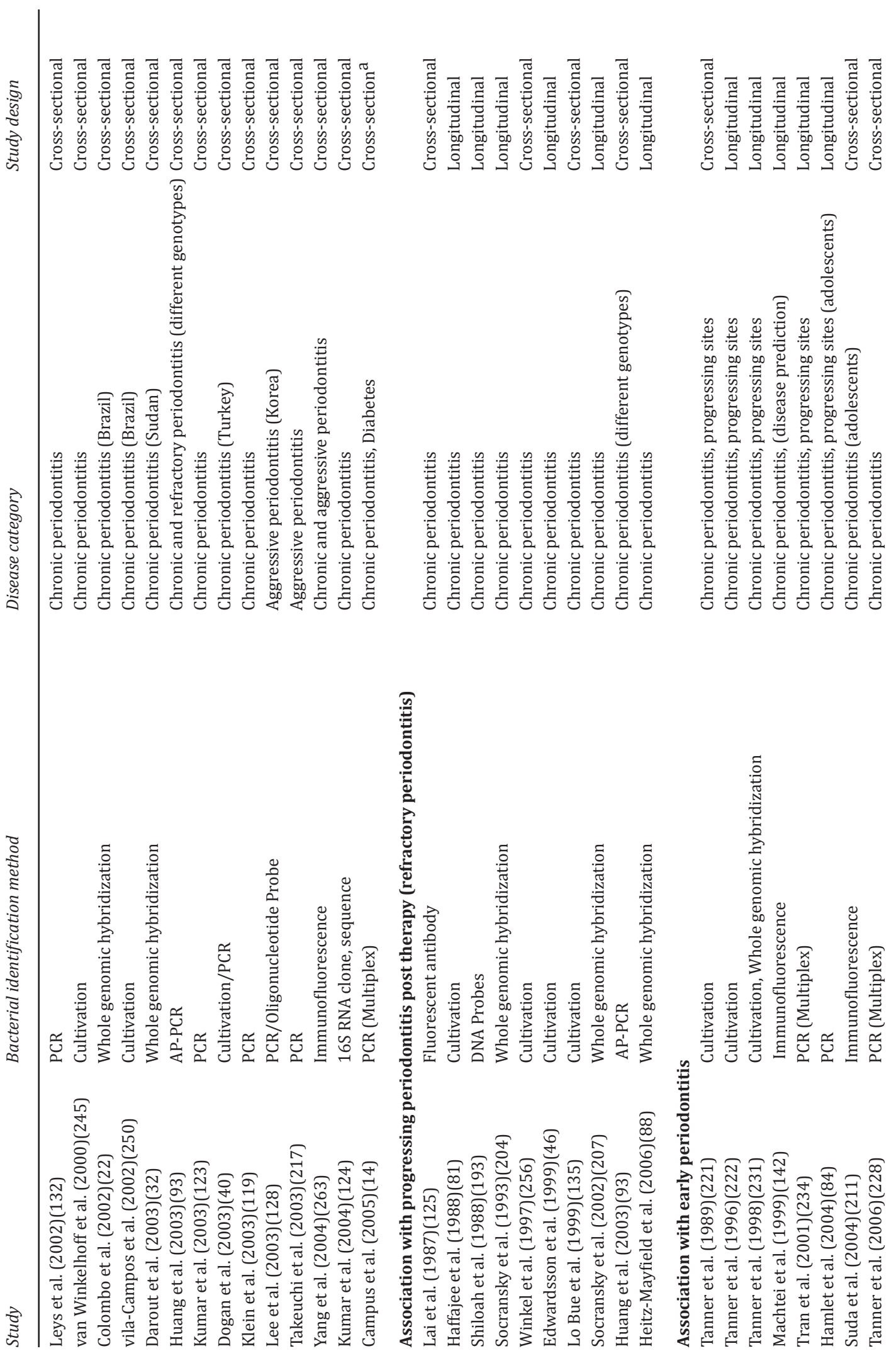

. 
allowed species amplification by assaying colonies of isolates rather than cells in plaque samples (74). Direct analysis of clinical samples using whole genomic DNA probes for T. forsythia had a sensitivity of $10^{3}$ to $10^{4}$ cells (138). Use of whole genomic probes was expanded by Socransky et al. (208) to analyze several species against multiple samples simultaneously using a "checkerboard" assay. This method can assay subgingival samples ranging in size from $10^{4}$ to $10^{7}$ cells in a sample. Larger samples can be analyzed by diluting samples, thus avoiding cross-reactivity between species analyzed using whole-genomic probes. A combination of culture and whole genomic checkerboard analysis was developed to assay antimicrobial susceptibility of subgingival samples (51) and artificial biofilms (209). In this assay all colonies from plates were harvested, the cells were diluted into the assay range, and tested against whole genomic probes in the checkerboard assay. Randomly cloned DNA probes to T. forsythia were more specific than whole genomic probes but less sensitive for species detection (258). Cloned probes are the basis of a commercial laboratory assay which is available in Europe (as DMDx/ PATHOTEK@)s (23).

DNA probe methods also use oligonucleotide probes to identify $T$. forsythia and other species in oral and clinical samples. Oligonucleotide probe detection (38) of T. forsythia and other selected species were used in the evaluation of local tetracycline therapy for periodontitis (68). These oligonucleotide probes included several different oligonucleotide sequences complementary to species-specific $16 \mathrm{~S}$ rRNA sequences to improve the sensitivity of species identification and quantification in clinical plaque samples. The reverse capture-oligonucleotide probe assay uses a similar checkerboard apparatus as that used in the whole genomic probe checkerboard assay. To use oligonucleotide probes, samples first undergo a polymerase chain reaction amplification using broadrange "universal" primers $(166,208)$. Microarrays or DNA chips represent a miniaturized version of assaying samples to multiple species using oligonucleotide DNA probes. One commercially available microarray, the ParoCheck $®$ (Greiner, Bio-One GmbH, Frickenhausen, Germany) includes T. forsythia among the 20 assayed species.

\section{Direct polymerase chain reaction methods}

Detection of several putative periodontal pathogens including T. forsythia directly from subgingival samples using species-specific primers 
in a polymerase chain reaction was described by Slots and co-workers $(6,201)$. Different primer sets have been described by a number of investigators to detect $T$. forsythia in periodontal samples $(84,119)$. Polymerase chain reaction methods were also used to detect $T$. forsythia in endodontic lesions (25). Multiplex polymerase chain reaction allows the detection of several species in a single polymerase chain reaction assay. Multiplex polymerase chain reaction assays including T. forsythia have been described $(14,15,24,233)$. Several recent reports describe the use of real-time polymerase chain reaction to quantify T. forsythia in samples $(106,122,127,180,214)$.

\section{Comparisons between identification methods}

\section{Culture and polymerase chain reaction-based methods}

Cultural detection of T. forsythia is compromised if $N$-acetylmuramic acid is not included in the isolation medium and too short ( $<10$ days) an incubation time is used for primary isolation. There are few comparisons between polymerase chain reaction followed by cloning and sequencebased identification and culture. One such comparison used five endodontic samples and reported that cultural techniques favored detection of Bacteroidetes over the polymerase chain reaction-based method. T. forsythia was detected in one subject by culture but not by the polymerase chain reactionbased method (157). This finding led to an improvement of the polymerase chain reaction primers, for Bacteroidetes (33) but no further comparisons with culture were reported.

Other studies comparing the cultural detection of T. forsythia with other methods, detected the species more frequently by non-cultural methods. Immunofluorescence assays detected T. forsythia, P. gingivalis, P. intermedia, and Campylobacter rectus, more frequently than by culture (62). Furthermore, comparisons between culture and rapid polymerase chain reaction-based methods for T. forsythia indicated increased detection frequency for the polymerase chain reaction methods. One study detected $21 \%$ culture positive compared with $27 \%$ positive in a multiplex polymerase chain reaction assay (49). Culture compared with real-time polymerase chain reaction indicated that all culture positive samples were detected by real-time polymerase chain reaction, but that culture failed to detect a further $28 \%$ of samples detected only by polymerase chain reaction (106). A more marked difference between culture and 
real-time polymerase chain reaction was reported by Lau et al. (127), with a detection of $T$. forsythia of $12 / 92$ by culture and $82 / 92$ by real time polymerase chain reaction, which detected all the culture positive samples.

\section{Culture and DNA probes}

A comparison between culture (with $N$-acetylmuramic acid in primary isolation plates) and whole genomic probes in the checkerboard assay also detected $T$. forsythia more frequently by the genetic assay than by culture (164). The T. forsythia was detected by both methods in $27 \%$ of samples, and by culture or probe in $11.5 \%$ and $61.5 \%$ of samples, respectively (164). An oligonucleotide probe assay comprising two probe sequences also detected $T$. forsythia more frequently than by culture (150). In that study 18/20 samples were probe-positive compared with 13/20 culture-positive. These authors observed that in probe-positive, culture-negative samples, T. forsythia was detected in very low proportions $(<1 \%)$ of the total microbiota (150), which was below the detection threshold for non-selective culture (150). Similar findings were reported using a similar composite probe to the latter report but used in a rapid chair-side assay $(226,236)$. Ali et al. (3) compared data from the same chair-side probe assay with culture data and detected a much higher proportion of T. forsythia-positive samples by probe (15/54) compared with anaerobic culture (3/54). In a second study that included whole genomic probe checkerboard assay, it was found that $28 \%$ and $18 \%$ of the samples were positive by probe and culture, respectively (2). The checkerboard assay, however, detected a higher proportion of positive samples (81\%) than the oligonucleotide test or culture (2). The ParoCheck $®$ (Greiner, Bio-One GmbH, Frickenhausen, Germany) microarray was more sensitive for T. forsythia than culture. T. forsythia was detected in eight of 20 root canals using the probe assay but was not detected by culture (249).

Other comparison studies did not include culture. A T. forsythia oligonucleotide probe, complementary to single 16S rRNA sequence, demonstrated good agreement with an immunofluorescence assay, suggesting similar sensitivities between the two assays for the detection of subgingival species (61). The whole genomic checkerboard assay and polymerase chain reaction for T. forsythia gave similar detection frequencies 
(197). Comparisons between end point and quantitative (real-time) polymerase chain reaction with an enzyme-linked immunosorbent assay indicated that the polymerase chain reaction assays were more sensitive than enzyme-linked immunosorbent assay (192).

Collectively these comparisons indicate that $T$. forsythia can be detected reliably and sensitively in samples using non-cultural methods. Use of oligonucleotide probes and polymerase chain reaction- based studies has the advantage of being less susceptible to cross-reactivity than whole genomic probe assays. Sequence-based methods, oligonucleotide probes and polymerase chain reaction have a further advantage in being able to assay cultured species and phylotypes for which there are currently no cultivated microorganisms, including Tannerella phylotypes (Fig 1 and 2).

\section{Association with oral infections}

\section{Association with periodontal infections}

Association with disease encompasses more frequent and/or higher levels of suspected pathogen detection in disease compared with health, and species suppression (elimination) with resolution of symptoms (58, 203). T. forsythia was first recognized from advanced periodontitis in subjects who had shown recent disease progression based on serial radiographs (225). The association of T. forsythia with periodontitis, including progressing (aggressive) periodontitis, has been observed in a number of studies from populations around the world (Table 1). Periodontitis that progresses post-therapy, "refractory " periodontitis, represents a particularly aggressive form of disease, which has also been associated with detection of T. forsythia (Table 1). Detection methods for the species include cultural, immunological, and genetic assays.

T. forsythia has also been associated with early or initial periodontitis (Table 1). It had been hypothesized that one set of species might initiate gingivitis, after which other species would initiate periodontitis. Detection of periodontal pathogens in gingivitis and early periodontitis suggests that similar species initiate both infections. T. forsythia has been associated with early stages of periodontal attachment loss by culture (231), immunofluorescence (142), and polymerase chain reaction (234). 


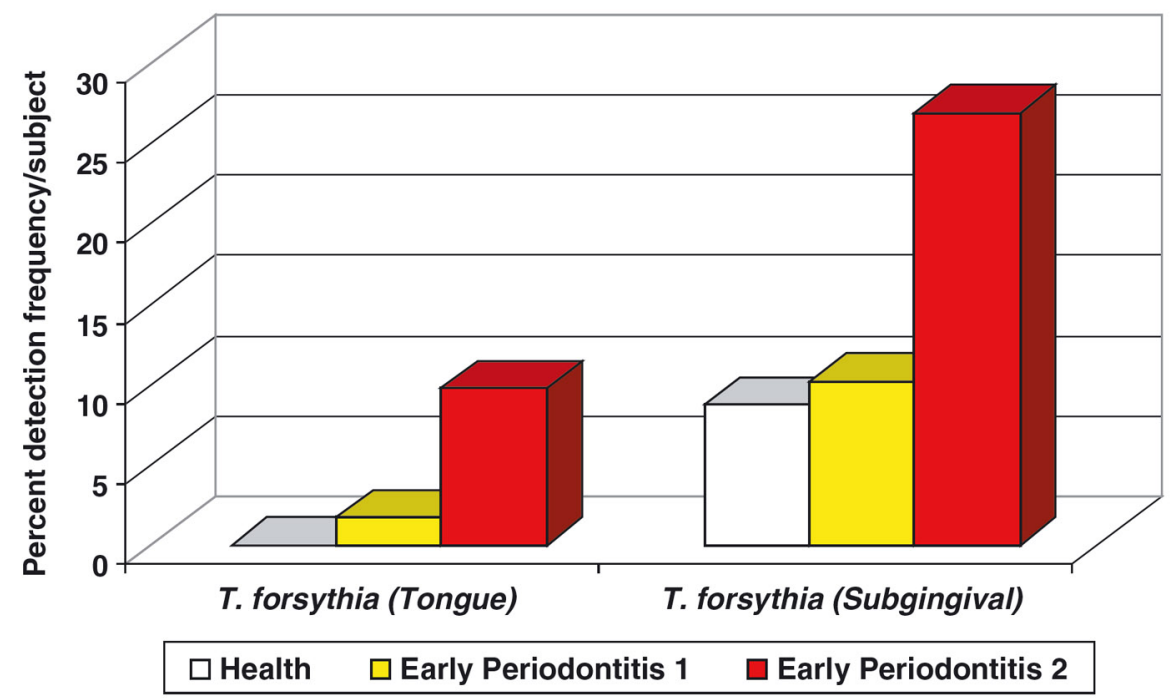

Fig. 4. Detection by PCR of Tannerella forsythia in 124 paired tongue and subgingival samples of 23 healthy (mean periodontal attachment level (AL) $\leq 1.5 \mathrm{~mm}$, no sites $>2$ mm AL loss), 59 early periodontitis 1 (mean AL $\leq 1.5 \mathrm{~mm}, \geq 1$ site more than $2 \mathrm{~mm} \mathrm{AL}$ loss) and 42 early periodontitis 2 (mean AL $>1.5 \mathrm{~mm}$ ) subjects. T. forsythia was detected more frequently subgingivally than from tongue samples $(\mathrm{P}=0.001)$. T. forsythia in subgingival samples $(\mathrm{P}<0.03)$ was associated with early periodontitis. Data derived from (228).

We recently examined early stages of periodontal attachment loss compared with periodontal health and compared the microbiota by polymerase chain reaction and $16 \mathrm{~S}$ rRNAbased oligonucleotide probes (228). Detection of T. forsythia was associated with early periodontitis in a comparison of subgingival and tongue samples from healthy subjects and those with early periodontitis in this cross-sectional analysis (Fig. 4). Detection associated with bleeding on probing or attachment loss in adolescents has also been recorded $(84,211)$, further suggesting an association with early periodontitis.

Suppression of a pathogen with resolution of disease represents further evidence for disease association. Studies that observed a reduction of T. forsythia associated with resolution of clinical symptoms of disease are summarized in Table 2. A range of therapies was used to achieve clinical improvement including scaling and root planing, local and/or systemic antibiotics, and periodontal surgery.

Risk factors for periodontitis have also been linked with increased detection of T. forsythia. Detection of T. forsythia was associated with 
Table 2. Studies linking suppression of $T$. forsythia post therapy with disease resolution

\begin{tabular}{llll} 
Study & Bacterial identification method & Therapy type & Study design \\
\hline Haffajee et al. (1996)(80) & Whole genomic hybridization & Periodontal surgery, systemic tetracycline & Longitudinal \\
Umeda et al. (1996)(239) & Cultivation IFA & Local minocycline & Longitudinal \\
Haffajee et al. (1997)(76) & Whole genomic hybridization & Scaling, root planing (SRP) & Longitudinal \\
Winkel et al. (1997)(256) & Cultivation & SRP, systemic metronidazole & Longitudinal \\
Winkel et al. (1998)(257) & Cultivation & Systemic amoxicillin and metronidazole & Longitudinal \\
Takamatsu et al. (1999)(215) & DNA probe, PCR & SRP & Longitudinal \\
Cugini et al. (2000)(27) & Whole genomic hybridization & SRP & Longitudinal \\
Darby et al. (2001)(31) & PCR & SRP & Longitudinal \\
De Soete et al. (2001)(34) & Whole genomic hybridization & SRP, chlorhexidine (whole mouth disinfection) & Longitudinal \\
Feres et al. (2001)(52) & Whole genomic hybridization & Systemic amoxicillin or metronidazole & Longitudinal \\
Van der Velden et al. (2003)(240) & Cultivation & SRP +/) surgery, antibiotics & Longitudinal \\
Rodrigues et al. (2004)(171) & Cultivation, DNA probes & SRP, tetracycline (systemic or local) & Longitudinal \\
Darby et al. (2005)(30) & PCR & SRP & Longitudinal \\
\hline
\end{tabular}

subjects who were smokers $(46,79,112,242,267)$, positive for aspartate aminotransferase activity (115), or interleukin-1 genotype (PST test) (206). Systemic disease is frequently associated with lowered resistance to infection, including periodontal infections. T. forsythia was associated with viral diseases (200), subjects infected with $\operatorname{HIV}(66,146)$, diabetes, (14), and Papillon-Lefe'vre syndrome (140,173).

Certain populations have an elevated risk of developing periodontitis, which might reflect differences in the subgingival microbiota. In the UK, P. gingivalis was detected more frequently in Indo- Pakistani adolescents compared with white-Caucasian and Afro-Caribbean adolescents (50). In Los Angeles (U.S.A.), P. gingivalis was also detected more frequently in advanced periodontitis in Asian patients compared with African-Americans and Caucasians, but the highest $P$. gingivalis detection frequencies were in Hispanic subjects, although these differences were not significant (237). In the same population, T. forsythia had similar detection frequencies between groups, T. forsythia was detected in $100 \%$ of Hispanic advanced periodontitis subjects. Craig et al. (26) reported lower serum immunoglobulin G levels to T. forsythia in Hispanic subjects. In the latter study, the differences in periodontitis, microbiota and host response were considered to be related more to environmental and demographic factors, including occupational status, than to race/ethnicity.

While T. forsythia has been associated with periodontitis, it was also detected in gingival and subgingival plaque in periodontally healthy subjects $(63,64)$. Detection in periodontal health may represent its presence 
in a "carrier state", which seems likely because levels are generally lower than those found in periodontal disease (Table 1). Furthermore, different bio- or genotypes may have different relationships with health or disease. Different phylotypes of Tannerella were associated with periodontal health compared with $T$. forsythia in periodontitis $(123,132)$. Detection of different genotypes, as determined by reverse transcriptionpolymerase chain reaction (138) or arbitrarily-primed-polymerase chain reaction (93), showed different disease associations. T. forsythia has also been detected in samples from the tongue, and was associated with halitosis (219). In our studies of healthy and early periodontitis T. forsythia was detected more frequently subgingivally than from the tongue (Fig. 4) (228), suggesting that the likely primary niche/habitat is subgingival. This observation was similar to that of other periodontal species detected using oligonucleotide probes, but contrasted with $P$. gingivalis which was associated with both tongue and subgingival sites (228).

Association with endodontic and peri-implant oral infections

T. forsythia is not exclusively associated with periodontal infections. Strains used in the taxonomy study originated from both periodontal and endodontic lesions. Taxonomic studies have looked at T. forsythia isolates from peri-apical infection (105) and from alveolar radiolucent lesions of endodontic origin (17). A number of other studies have identified $T$. forsythia from dental root canals by polymerase chain reaction $(25,55,107,176,195)$, DNA probes $(59,198,213)$, or microarray (DNA chip) (249). It was detected in periapical tissues using fluorescent in situ hybridization (FISH) (Fig. 5) (212). Subgingival T. forsythia is the likely source in endodontic pathology (176), and for infections around dental implants $(129,130,243)$; T. forsythia was associated with peri-implantitis by culture (223) and by DNA probes (98). The microbiota of failing implants was similar to that of refractory periodontitis (133).

\section{Source of T. forsythia detection in children}

An early indication that $T$. forsythia might be detected in children and transmitted from parent to child came from data using the BANAbased assay (183). T. forsythia was detected by polymerase chain reaction from tube-fed children (18), Down syndrome children (4), and 


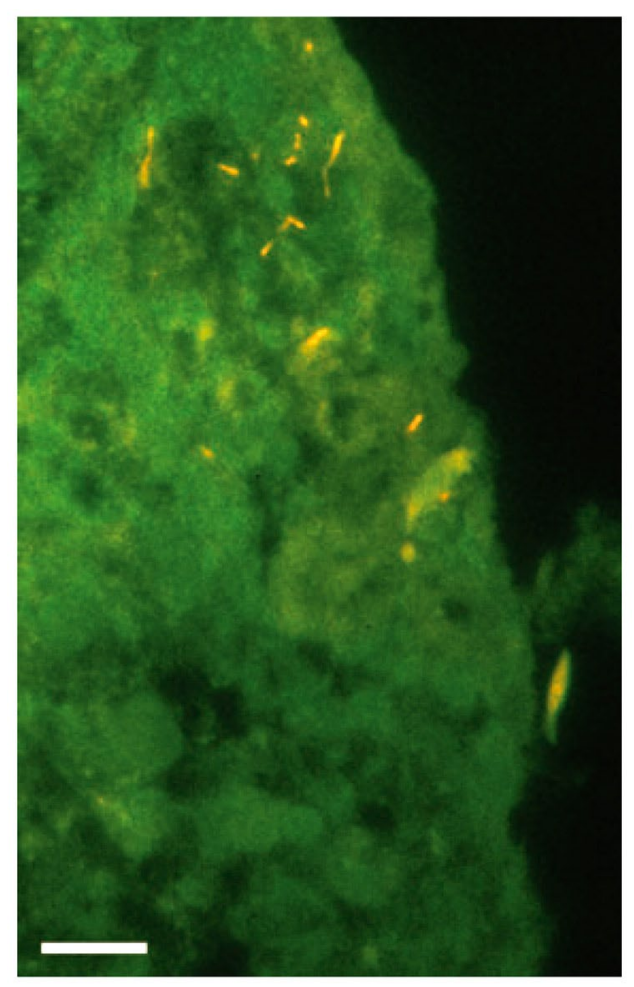

Fig. 5. Visualization of Tannerella forsythia by FISH on tissue sections from a periapical endodontic lesion. Simultaneous hybridization was performed with the bacteria-specific probe EUB 338-FTIC (green), and the species-specific probe T. forsythia-Cy3 (orange) (212). Reprinted with the permission of the Society for General Microbiology.

children with periodontitis (159), but was found infrequently in medically healthy children (118), also infrequently in children when using cultural detection $(110,111)$. It was detected using DNA probes in a population-based study of preschool children with a high prevalence of dental caries (227). In that population there were increased odds of species detection in the child if the child's parent was also positive (227). In the children, T. forsythia detection was associated with gingival bleeding, and a higher odds that $T$. forsythia would be detected if the mother had periodontitis (262). Polymerase chain reaction detection of T. forsythia in children was also linked to its detection in a parent $(160,218,238)$. These studies suggested that $T$. forsythia, like other periodontal pathogens, is endogenous and primary infection likely occurs by vertical transmission.

While T. forsythia was detected in health, and gingivitis, the species was detected more frequently associated with disease than health, indicating, that in the oral cavity T. forsythia shows a defined association with periodontal, peri-implant, and endodontic pathology. 


\section{Cell and tissue invasion in humans}

T. forsythia has been detected in host tissues; it was detected on or in crevicular epithelial cells from healthy and periodontally diseased patients (37) by DNA probes. The penetration of T. forsythia within the different layers of tissue has been shown by microscopy $(177,212)$. The progress made using FISH microscopy-based technology enables investigators to observe a fragment of tissue and selectively detect one or more organisms. Using a probe specific to one organism, or a probe that is universal to bacteria, the load and distribution of the organism within the sample can be observed. Such techniques have been applied successfully to periodontal tissues $(174,254)$, and to periapical lesions (Fig. 5) (212).

Localization of T. forsythia within buccal epithelial cells from subjects has been recently described using FISH (175). Surprisingly, the cells were neither monoinfected, nor were T. forsythia, P. gingivalis or Actinobacillus actinomycetemcomitans, the major invading bacteria. Other tissue-invading cells were species of Streptococcus (175). This finding suggests that a wide range of species may invade host cells, perhaps providing a strategy for bacterial persistence.

The increasing association of systemic disease with periodontal infection led to periodontal species being sought in extra-oral host tissues, mainly using polymerase chain reaction-based methods. Polymerase chain reaction was used to identify T. forsythia in atheromatous plaques (85), in coronary stenotic artery plaques (101), in atherosclerotic vessels (54), and in occluded arteries of patients with Buerger disease (103). T. forsythia was also detected in the bronchial tissues of embalmed cadavers (259). Future study will clarify whether this periodontal species is contributing to the pathology in these clinical conditions.

\section{T. forsythia in animal models of infection}

Mono- and mixed infections with T. forsythia in animal models provide an opportunity to examine the cooperative and competitive components of polymicrobial oral infections. Several animal models have been used to study the pathogenic potential of $T$. forsythia in periodontal and endodontic infections. As a mono-infection, T. forsythia was among the species, including P. gingivalis and F. nucleatum, that induced alveolar bone loss in gnotobiotic rat infections (220). Rabbits and mice were used to 
test its pathogenicity in a subcutaneous abscess model $(10,216)$. More recently more technically challenging models of mouse gingival tissue $(1,7,190)$, and endodontic infections have been used to mimic oral challenges and outcomes $(8,56,185)$.

Mono- and mixed infections of T. forsythia, P. gingivalis, and F. nucleatum were tested in a wound chamber model in rabbits (216). While there was no abscess formation in mono-infections involving individual species, infection by $T$. forsythia plus $P$. gingivalis resulted in abscess formation in all tested animals, whereas T. forsythia and F. nucleatum mixed infections resulted in abscesses in $75 \%$ of the tested animals. The synergistic effect of $T$. forsythia and $P$. gingivalis was also observed in mice (265). These results indicated that the ability of T. forsythia to invade tissues is not only dependent on the characteristics of the strain (species) used but may result from interspecies interactions. A periodontal challenge of $P$. gingivalis, $B$. fragilis, $B$. vulgatus, $P$. intermedia, and $T$. forsythia resulted in alveolar bone loss and exposure of molar tooth roots (1). Using a mouse model for endodontic infection it has been shown that a mixed infection of $P$. gingivalis, T. denticola, and T. forsythia induced periapical bone loss (56).

\section{From association with infection to the definition of a pathogen}

Both clinical studies in humans, and animal model studies, associate $T$. forsythia with disease. Designating a bacterial species as a pathogen includes associating the species with disease and associating the species with pathogenicity-related factors that include host response, virulence factors, and molecular signatures $(58,170)$.

Determination of the cell components thought to be important in pathogenicity starts with identification of their effects on the host. Both the cell biology of T. forsythia and its effect on the host are still largely unknown. Three areas of research are underway:

- understanding the components of T. forsythia cell biology that are needed for a population to settle in a niche, which may also have deleterious effects on the host.

- identifying strategies of biofilm formation and maintenance.

- understanding the host-bacteria cross-talk that forms the basis of health, disease, and healing. 
These three areas of research provide opportunities to intervene in disease-associated colonization and persistence. Not all of these components are considered traditional pathogenic factors, but they contribute to successful colonization and loss of biofilm control by the host. The availability of the genome sequence, a nascent genetic system, and animal models, provide tools to evaluate and define the pathogenic potential of a species, and create opportunities to experiment with new treatment strategies.

\section{Genome sequence of T. forsythia}

The full genome of T. forsythia type strain, ATCC 43037, has been sequenced. The strain was provided by F.E. Dewhirst and M.F.J. Maiden of The Forsyth Institute. The cloning, sequencing, and assembly of the genetic sequence were performed by Steven Gill and colleagues at the TIGR Institute. The primary annotation and web-site presentation are available through the Oral Pathogen Sequence Databases at Los Alamos National Laboratory Bioscience Division (http://www.oralgen.lanl.gov ). The dynamic annotation compiling all available genetic sources is available through the Bioinformatics Resource for Oral Pathogens at The Forsyth Institute (http://www.brop.org ) (19).

The genome contains 3,405,543 base pairs, and 3,034 predicted open reading frames. The GC content is $46.8 \%$. Two $16 \mathrm{~S}$ rRNA sequences are present in the genome. Phage and transposons are encoded within the genome but their function has not yet been investigated. Fifteen genomic (pathogenicity) islands were detected, including the Bacteroides conjugative transposon-related island, tra gene cluster (http://www.oralgen. lanl.gov). The tra genes are organized in the same order in $P$. gingivalis and $P$. intermedia. A detailed analysis of the genome sequence will be provided with the release of the primary publication.

Information from the genome sequence of a pathogen can expand the study of a specific species through new technologies and by comparing genetic potential with other organisms. Data from genome sequences facilitate the investigation of critical events in the cell biology, the infectious process, and dialog between host and pathogen, or between microorganisms. The major goal of genome-enabled infectious disease research is the development of novel diagnostics and therapeutic strategies, both requiring a deeper understanding of the genetic makeup of the organism and the host, and the organism's expression potential (57). 


\section{A genetic system in its infancy}

Only one group so far has successfully created a T. forsythia strain with a genetically altered gene (92). Honma et al. (92) used a suicide plasmid and a triparental conjugation. The suicide plasmid was constructed in an Escherichia coli replicating plasmid that cannot replicate in T. forsythia, containing $b s p A$ (targeted gene for the genetic interruption) and tet(Q) for tetracycline antibiotic selection. Genetic exchange was enabled by E. coli RK231, supplying the conjugal transfer function, between the E. coli strain carrying the suicide plasmid and T. forsythia ATCC 43037. The resulting clone contained a $b s p A$ gene interrupted by the insertion of the full plasmid (92). New, more efficient methodologies for genetic engineering may arise from analyzing the genome sequence. No functional reporter gene has been published but it is suggested that Bacteroides reporter genes may be of use.

\section{T. forsythia cell biology: the foundation for population survival and expansion}

Integral components of pathogenicity frequently have their origin in bacterial cell physiology. Understanding the bacteria-host interactions that are important in pathogenicity start, for example, from knowing which

proteases facilitate bacterial nutritional requirements while enhancing tissue destruction (178).

Molecular-method-based data complement information obtained from biochemical characterization. Functional characterization without gene identification, and vice versa, however, can provide only a weak understanding of the cell's potential and/or its activity in the environment where challenges lie. To understand the complexity of the hostpathogen relationships, we need to move beyond the study of isolated individual biological components (genes, proteins, etc.) to study how the individual components cooperate. This integrative knowledge involves a functional study of cell components, a genomewide understanding of cell functions, their relationships, and the effects of products and by-products on their environment. This may be related to the same organism (quorum sensing, attachment to human cell, methylglyoxal toxicity, etc.), another member of the biofilm (growth stimulation, bacteriotoxin production, genetic exchange mediating antibiotic resistance, 
etc.), or the host (innate immune response stimulation, inflammation, bone resorption, etc.).

Several genes of $T$. forsythia were sequenced before the full genome was sequenced. These T. forsythia genes included: the sialidase siaHI (102), the superoxide dismutase $\operatorname{sod} F$ (97), an $\alpha$-D-glucosidase (97), an $N$-acetyl- $\beta$-glucosaminidase (97) the outer membrane $\operatorname{Rag} A$-like gene (97), groEL (169), prtH protease with hemolysin activity (178), bspA (191), susB (97), a formate channel (A. Nagai and N. Itoh, GenBank deposit, unpublished data), EF-Tu (A. Nagai and N. Itoh, Genbank deposit, unpublished data), and an unusual sigma factor common to the members of the Bacteroidetes phylum (252).

Binding of pathogens to tissues can be mediated through fibronectin binding activity. Binding of T. forsythia cells to immobilized fibronectin and fibrinogen was decreased in fibronectin- and fibrinogen-coated microtiter plates in a $b s p A$ genetically engineered strain that did not express BspA (92). Purified recombinant BspA protein competes with binding of a T. forsythia wild-type strain to fibronectin and fibrinogen on fibronectin- and fibrinogen-coated microtiter plates (191). BspA is immunogenic in patients with periodontitis (191). The BspA protein belongs in the leucine-rich repeat (LRR) protein family. The amino acid sequence includes leucine-rich repeat motifs, which is a versatile protein-binding motif. Most proteins belonging to the LRR family interact via protein- protein interaction in a receptor-ligand context $(108,120)$. Methylglyoxal is a pathogenic mediator produced by T. forsythia; a byproduct of metabolism, it has cytotoxic effects on bacteria and host (116, 144). It is principally associated with the glycolytic pathway and allows the cell to control the rate of carbon efflux (53). Methylglyoxal accumulates in cultures of a variety of microorganisms, and in human tissues and it reacts with proteins to form advanced glycation end products toxic for bacterium and host. In response, organisms frequently use multiple defensive metabolic mechanisms for detoxifying methylglyoxal (109). In the gingival crevicular fluid methylglyoxal was detected at higher concentrations in subjects with periodontal disease than in healthy subjects (116). The contribution of inflamed tissue to the total amount of methylglyoxal is unclear. This reactive compound may contribute significantly to tissue damage in periodontal disease.

The enzymatic activities of T. forsythia include a trypsin-like protease (71) source of the BANA test, a $\beta$-lactamase (246), as well as phos- 
phatase, peptidase, sugar-degradation, and lipase used for identification $(145,179,230,232)$.

\section{T. forsythia biofilm formation and maintenance}

T. forsythia is a component of the biofilms found in the oral cavity. The dynamics of biofilm formation in oral infections is complex in both structure and composition over time. There are interactions between species, competition between species, in addition to host influences on biofilm organization. These interactions may differ during disease progression, persistence or remission. The spatial bacterial organization within dental plaque in vivo may result from co-aggregation-dependent growth stimulation between pairs of organisms in the biofilm (162). Co-adherence between species and species-tospecies communication may also be key components for biofilm organization, helping or establishing spatiotemporal development $(48,121)$. Understanding and elucidating the dynamics of biofilm composition and structure is an incremental process. Analysis of mono-species and two-species biofilms facilitates understanding the intricate communication and interrelationships of polymicrobial biofilms involved in oral health and diseases.

T. forsythia can form biofilms in vitro with F. nucleatum (190). The thickness and structure of T. forsythia biofilms is influenced by F. nucleatum. Both species co-aggregate when in a planktonic form (190), and this interspecies binding appears to be critical in the formation and structure of T. forsythia- F. nucleatum biofilms, and favors T. forsythia growth (190). This type of interaction was not observed for the biofilms formed by T. denticola with P. gingivalis (248) and by Streptococcus oralis with Actinomyces naeslundii (162). Could the T. forsythia-F. nucleatum interaction facilitate intergenic exchange? This question, of interest for all oral organisms, can be addressed by analysis of both available genomes followed by experimental exchange of DNA.

Both F. nucleatum and T. denticola can bind to T. forsythia (99). Co-aggregation between T. forsythia and T. denticola is influenced by two LRR proteins, BspA and LrrA, for T. forsythia and T. denticola, respectively (99). In vitro binding assay between the two proteins, BspA and LrrA, expressed and purified as recombinant full and truncated forms, shows that the N-terminal region of LrrA, but not the LRR domain, is involved in the binding process (99). Other surfaceexposed proteins may also be 
involved in cell-to-cell attachment; T. forsythia bspA is regulated by contact when forming a biofilm with $F$. nucleatum (100). Decrease of $b s p A$ transcription compared with planktonic cultures occurs while $T$. forsythia is forming a biofilm by itself, or with F. nucleatum (100).

\section{Host response to T. forsythia}

Animal models and in vitro cell culture models reveal the aggressiveness of T. forsythia in infection, and host-bacteria interactions. The immune response to T. forsythia was examined using a mouse abscess model. Live and non-viable T. forsythia cells were injected subcutaneously in the dorsum on the mouse. The mice developed lesions consisting of granulomatous tissue with a large central core. There was primarily an innate immune response, neutrophils being the dominant leukocyte 1 day after injection (69). Consequently, there was no evasion of the innate host defense mechanism, unlike for $P$. gingivalis (69). The immune reaction was greater with larger skin lesions using live T. forsythia compared to non-viable organisms (69). Cell culture in vitro analysis of host-bacteria interactions allows investigation of mechanistic components of health, disease or the healing process. The inflammatory response of a macrophage/ epithelial cell co-culture to mono- and mixed infection with $P$. gingivalis, T. denticola, and T. forsythia was recently investigated (11). The 1:5 ratio of macrophage: epithelial cells was chosen to represent an inflamed periodontium. In this model P. gingivalis, T. denticola, and T. forsythia stimulated the secretion of pro-inflammatory cytokines (interleukin-1b, interleukin-6), chemokines (interleukin-8, RANTES), prostaglandin $\mathrm{E}^{2}$, and matrix metalloproteinase- 9. These oral pathogens have strong potential for activating host-mediated destructive processes. No synergistic effect was observed for cytokine, chemokine, prostaglan$\operatorname{din} \mathrm{E}_{2}$, and matrix metalloproteinase- 9 production between mixed and mono-infections (11).

Cell apoptosis induced by T. forsythia was first demonstrated using a whole cell extract (5), and later using a T. forsythia lipoprotein fraction obtained by Triton X-114 phase separation (87). The same lipoprotein fraction also induced dose-dependent IL- 6 production by gingival fibroblasts and an epithelial cell line (87). The indirect effect of lipoproteins on disease progression has been hypothesized (87). Under this hypothesis, the membrane fraction containing lipoproteins of T. forsythia induced 
pro-inflammatory cytokines from gingival fibroblasts, monocytes, and macrophages, resulting in periodontal tissue destruction, bone resorption, and release of enzymes that degraded the extracellular matrix. Accumulation of the membrane fraction of T. forsythia in inflamed areas could then kill epithelial cells and gingival fibroblasts through apoptosis. Other oral organisms use similar strategies, or produce factors that lead to cell apoptosis $(5,86)$.

An external serrated S-layer is easily distinguishable in stained cell cross-sections observed by electron microscopy (Fig. 3) $(155,177,232)$. This S-layer structure is the first cell ultrastructure encountered by the environment and the host. S-layer proteins are immunogens in periodontitis patients (177). The S-layer also mediates hemagglutination, which is inhibited by $\mathrm{N}$-acetylglucosamine, and heat denaturation of the proteins. Polyclonal antibodies directed towards the S-layer also inhibit hemagglutination, as well as cell adherence and cell penetration into KB-cell lines (cell lines derived from epidermal carcinoma of the mouth) (177). Pre-immunization of mice with S-layer protected these animals against abscess formation after challenge with live T. forsythia cells (177). The nature of the hemagglutinin is still unknown. At least one hemagglutinin was inhibited by $N$-acetylneuraminyllactose (158), and this/these proteins may differ from the 200/210-kDa protein described by Sabet et al. (177). Progress will be made by exploring relationships between gene, protein, and antigens to understand the organism's relationships with its environment.

The immune response to T. forsythia may have implications for another oral pathogen. Both P. gingivalis and T. forsythia were found to share common antigens providing some level of immune protection (247). This reactivity was observed when the primate Macaca fascicularis was vaccinated with killed P. gingivalis, or when New Zealand White rabbits were immunized with $P$. gingivalis or T. forsythia. This cross-reactivity, however, was not observed with A. actinomycetemcomitans. Antibodies to shared lipopolysaccharide epitopes among oral pathogens or members of the oral microbiota may account, in part, for the immune protection observed in immunized monkeys (247). A direct consequence of this crossreactivity could lead to modulation of the duration and intensity of infection. If the patient was already challenged by a particular pathogen, when another species infects that shares common epitopes, the progress of the population invasion and maintenance may 
be significantly altered. This may account for some of the variation observed in host susceptibility to periodontal diseases. Additional population variation in periodontitis and caries susceptibility was attributed to genetic factors, based on studies in twins $(13,147)$.

\section{Summary, perspective and future opportunities}

In this review, we have described T. forsythia from the perspective of the microbiologist, and its associations with periodontal and other oral infections. To assess pathogenic potential one needs to go further than association with disease. One needs to associate pathogenic mechanisms and mediators with host response. The availability of the full genome sequence data for a strain of $T$. forsythia isolated from a progressing lesion of advanced periodontitis opens new horizons for our understanding of Tannerella sp.-Tannerella sp., Tannerella sp.-microbiome, and Tannerella sp.-host interactions. New technologies are becoming available to study this species and others in the genus, which will provide new insights into the cell biology of the bacteria and the host. The quantum leap provided by a full genome will greatly enhance the analytic power of proteomics, transposomics, genomics, and bioinformatics to be applied to this species. While the first steps will appear mainly to benefit basic science, translation researchers and clinicians will subsequently be able to incorporate those findings to improve care and disease prevention.

Acknowledgments As a result of the large number of articles concerning bacterial association and oral diseases, we apologize to those whose work has not been included in this review. We thank Steven R. Gill from TIGR for providing in advance of publication the full genome sequence of $T$. forsythia, project supported by a grant from NIH-NIDCR U01-DE13914. We thank Floyd E. Dewhirst for Fig 1 and 2 (NIH-NIDCR DE10374). We thank Pia T. Sunde and Max Listgarten for permission to use their figures for this review. The authors are supported by NIH-NIDCR DE14264, DE015594, DE015847 (A.T.) and the John W. Hein Research Fellowship (J.I.).

\section{References}

1. Al-Rasheed A, Scheerens H, Rennick DM, Fletcher HM, Tatakis DN. Accelerated alveolar bone loss in mice lacking interleukin-10. J Dent Res 2003: 82: 632-635. 
2. Ali RW, Johannessen AC, Dahlen G, Socransky SS, Skaug N. Comparison of the subgingival microbiota of periodontally healthy and diseased adults in northern Cameroon. J Clin Periodontol 1997: 24: 830-835.

3. Ali RW, Velcescu C, Jivanescu MC, Lofthus B, Skaug N. Prevalence of 6 putative periodontal pathogens in subgingival plaque samples from Romanian adult periodontitis patients. J Clin Periodontol 1996: 23: 133-139.

4. Amano A, Kishima T, Kimura S, Takiguchi M, Ooshima T, Hamada S, Morisaki I. Periodontopathic bacteria in children with Down syndrome. J Periodontol 2000: 71: 249-255.

5. Arakawa S, Nakajima T, Ishikura H, Ichinose S, Ishikawa I, Tsuchida N. Novel apoptosis-inducing activity in Bacteroides forsythus: a comparative study with three serotypes of Actinobacillus actinomycetemcomitans. Infect Immun 2000: 68: 4611-4615.

6. Ashimoto A, Chen C, Bakker I, Slots J. Polymerase chain reaction detection of 8 putative periodontal pathogens in subgingival plaque of gingivitis and advanced periodontitis lesions. Oral Microbiol Immunol 1996: 11: 266-273.

7. Baker PJ, Dixon M, Roopenian DC. Genetic control of susceptibility to Porphyromonas gingivalis-induced alveolar bone loss in mice. Infect Immun 2000: 68: 5864-5868.

8. Balto K, Muller R, Carrington DC, Dobeck J, Stashenko P. Quantification of periapical bone destruction in mice by micro-computed tomography.J Dent Res 2000: 79: 35-40.

9. Baughn AD, Malamy MH. The strict anaerobe Bacteroides fragilis grows in and benefits from nanomolar concentrations of oxygen. Nature 2004: 427: 441-444.

10. Bird PS, Shakibaie F, Gemmell E, Polak B, Seymour GJ. Immune response to Bacteroides forsythus in a murine model. Oral Microbiol Immunol 2001: 16: 311-315.

11. Bodet C, Chandad F, Grenier D. Inflammatory responses of a macrophage/ epithelial cell co-culture model to mono and mixed infections with Porphyromonas gingivalis, Treponema denticola, and Tannerella forsythia. Microbes Infect 2006: 8: 27-35.

12. Braham PH, Moncla BJ. Rapid presumptive identification and further characterization of Bacteroides forsythus. J Clin Microbiol 1992: 30: 649-654.

13. Bretz WA, Corby PM, Schork NJ, Robinson MT, Coelho M, Costa S, Melo-Filho MR, Weyant RJ, Hart TC. Longitudinal analysis of heritability for dental caries traits. J Dent Res 2005: 84: 1047-1051.

14. Campus G, Salem A, Uzzau S, Baldoni E, Tonolo G. Diabetes and periodontal disease: a case-control study. J Periodontol 2005: 76: 418-425.

15. Caposio P, Torta AI, Romano F, Aimetti M, Romagnoli R, Marchiaro G, Cirillo DM. Molecular approaches to the identification and treatment monitoring of periodontal pathogens. New Microbiol 2003: 26: 121-124.

16. Chan Y, Chien R. Identification and analyses of periodontal pathogens in Taiwan by microbiological tests. Zhonghua Min Guo Wei Sheng Wu Ji Mian Yi Xue Za Zhi 1994: 27: 59-69. 
17. Chemel D. Bacteriology of lesions of endodontic origin. Masters Thesis. Boston University Medical Center Alumni Library, Boston, MA; 1984.

18. Chen C, Ashimoto A, Sangsurasak S, Flynn MJ, Slots J. Oral food consumption and subgingival microorganisms: subgingival microbiota of gastrostomy tube-fed children and healthy controls. J Periodontol 1997: 68: 1163-1168.

19. Chen T, Abbey K, Deng WJ, Cheng MC. The bioinformatics resource for oral pathogens. Nucleic Acids Res 2005: 33(Web Server issue): W734-W740.

20. ChoiBK, Park SH, Yoo YJ, Choi SH, Chai JK, Cho KS, Kim CK. Detection of major putative periodontopathogens in Korean advanced adult periodontitis patients using a nucleic acid-based approach. J Periodontol 2000: 71: 1387-1394.

21. Christersson LA, Fransson CL, Dunford RG, Zambon JJ. Subgingival distribution of periodontal pathogenic microorganisms in adult periodontitis. J Periodontol 1992: 63: 418-425.

22. Colombo AP, Teles RP, Torres MC, Souto R, Rosalem WJ, Mendes MC, Uzeda M. Subgingival microbiota of Brazilian subjects with untreated chronic periodontitis. J Periodontol 2002: 73: 360-369.

23. Conrads G. DNA probes and primers in dental practice. Clin Infect Dis 2002: 35(Suppl. 1): S72-S77.

24. Conrads G, Flemmig TF, Seyfarth I, Lampert F, Lutticken R. Simultaneous detection of Bacteroides forsythus and Prevotella intermedia by 16S rRNA genedirected multiplex PCR. J Clin Microbiol 1999: 37: 1621-1624.

25. Conrads G, Gharbia SE, Gulabivala K, Lampert F, Shah HN. The use of a 16s rDNA directed PCR for the detection of endodontopathogenic bacteria. J Endod 1997: 23: 433-438.

26. Craig RG, Boylan R, Yip J, Mijares D, Imam M, Socransky SS, Taubman MA, Haffajee AD. Serum IgG antibody response to periodontal pathogens in minority populations: relationship to periodontal disease status and progression. $J$ Periodontal Res 2002: 37: 132-146.

27. Cugini MA, Haffajee AD, Smith C, Kent RL Jr, Socransky SS. The effect of scaling and root planing on the clinical and microbiological parameters of periodontal diseases: 12-month results. J Clin Periodontol 2000: 27: 30-36.

28. Daneshmand N, Jorgensen MG, Nowzari H, Morrison JL, Slots J. Initial effect of controlled release chlorhexidine on subgingival microorganisms. J Periodontal Res 2002: 37: 375-379.

29. Darby IB, Hodge PJ, Riggio MP, Kinane DF. Microbial comparison of smoker and non-smoker adult and early-onset periodontitis patients by polymerase chain reaction. J Clin Periodontol 2000: 27: 417-424.

30. Darby IB, Hodge PJ, Riggio MP, Kinane DF. Clinical and microbiological effect of scaling and root planing in smoker and non-smoker chronic and aggressive periodontitis patients. J Clin Periodontol 2005: 32: 200-206.

31. Darby IB, Mooney J, Kinane DF. Changes in subgingival microflora and humoral immune response following periodontal therapy. J Clin Periodontol 2001: 28: 796-805. 
32. Darout IA, Skaug N, Albandar JM. Subgingival microbiota levels and their associations with periodontal status at the sampled sites in an adult Sudanese population using miswak or toothbrush regularly. Acta Odontol Scand 2003: 61: 115-122.

33. de Lillo A, Booth V, Kyriacou L, Weightman AJ, Wade WG. Culture-independent identification of periodontitis-associated Porphyromonas and Tannerella populations by targeted molecular analysis. J Clin Microbiol 2004: 42: 5523-5527.

34. De Soete M, Mongardini C, Peuwels M, Haffajee A, Socransky S, van Steenberghe D, Quirynen M. One-stage full-mouth disinfection. Long-term microbiological results analyzed by checkerboard DNA-DNA hybridization.J Periodontol 2001: 72: 374-382.

35. Di Murro C, Paolantonio M, Pedrazzoli V, Lopatin DE, Cattabriga M. Occurrence of Porphyromonas gingivalis, Bacteroides forsythus, and Treponema denticola in periodontally healthy and diseased subjects as determined by an ELISA technique. J Periodontol 1997: 68: 18-23.

36. Diaz PI, Rogers AH. The effect of oxygen on the growth and physiology of Porphyromonas gingivalis. Oral Microbiol Immunol 2004: 19: 88-94.

37. Dibart S, Skobe Z, Snapp KR, Socransky SS, Smith CM, Kent R. Identification of bacterial species on or in crevicular epithelial cells from healthy and periodontally diseased patients using DNA-DNA hybridization. Oral Microbiol Immunol 1998: 13: 30-35.

38. Dix K, Watanabe SM, McArdle S, Lee DI, Randolph C, Moncla B, Schwartz DE. Species-specific oligodeoxynucleotide probes for the identification of periodontal bacteria. J Clin Microbiol 1990: 28: 319-323.

39. Doan N, Contreras A, Flynn J, Morrison J, Slots J. Proficiencies of three anaerobic culture systems for recovering periodontal pathogenic bacteria. J Clin Microbiol 1999: 37: 171-174.

40. Dogan B, Antinheimo J, Cetiner D, Bodur A, Emingil G, Buduneli E, Uygur C, Firatli E, Lakio L, Asikainen S. Subgingival microflora in Turkish patients with periodontitis. J Periodontol 2003: 74: 803-814.

41 Duncan MJ. Oral microbiology and genomics. Periodontol 2000 2005: 38: 63-71.

42. Dzink JL, Smith CM, Socransky SS. Development of a broth medium for Bacteroides forsythus. J Clin Microbiol 1987: 25: 925.

43. Dzink JL, Tanner AC, Haffajee AD, Socransky SS. Gram negative species associated with active destructive periodontal lesions. J Clin Periodontol 1985: 12: 648-659.

44. Ebersole JL, Frey DE, Taubman MA, Smith DJ, Socransky SS, Tanner AC. Serological identification of oral Bacteroides spp. by enzyme-linked immunosorbent assay. J Clin Microbiol 1984: 19: 639-644.

45. Ebersole JL, Taubman MA, Smith DJ, Frey DE. Serological classification of Bacteroides from the human oral cavity. J Periodontal Res 1988: 23: 22-27.

46. Edwardsson S, Bing M, Axtelius B, Lindberg B, Soderfeldt B, Attstrom R. The microbiota of periodontal pockets with different depths in therapy-resistant periodontitis. J Clin Periodontol 1999: 26: 143-152. 
47. Egert M, Wagner B, Lemke T, Brune A, Friedrich MW. Microbial community structure in midgut and hindgut of the humus-feeding larva of Pachnoda ephippiata (Coleoptera: Scarabaeidae). Appl Environ Microbiol 2003: 69: 6659-6668.

48. Egland PG, Palmer RJ Jr, Kolenbrander PE. Interspecies communication in Streptococcus gordonii-Veillonella atypica biofilms: signaling in flow conditions requires juxtaposition. Proc Natl Acad Sci U S A 2004: 101: 16917-16922.

49. Eick S, Pfister W. Comparison of microbial cultivation and a commercial PCR based method for detection of periodontopathogenic species in subgingival plaque samples. J Clin Periodontol 2002: 29: 638-644.

50. Ellwood R, Worthington HV, Cullinan MP, Hamlet S, Clerehugh V, Davies R. Prevalence of suspected periodontal pathogens identified using ELISA in adolescents of differing ethnic origins. J Clin Periodontol 1997: 24: 141-145.

51. Feres M, Haffajee AD, Allard K, Som S, Goodson JM, Socransky SS. Antibiotic resistance of subgingival species during and after antibiotic therapy. J Clin Periodontol 2002: 29: 724-735.

52. Feres M, Haffajee AD, Allard K, Som S, Socransky SS. Change in subgingival microbial profiles in adult periodontitis subjects receiving either systemicallyadministered amoxicillin or metronidazole. J Clin Periodontol 2001: 28: 597-609.

53. Ferguson GP, Totemeyer S, MacLean MJ, Booth IR. Methylglyoxal production in bacteria: suicide or survival? Arch Microbiol 1998: 170: 209-218.

54. Fiehn NE, Larsen T, Christiansen N, Holmstrup P, Schroeder TV. Identification of periodontal pathogens in atherosclerotic vessels. J Periodontol 2005: 76: 731- 736 .

55. Foschi F, Cavrini F, Montebugnoli L, Stashenko P, Sambri V, Prati C. Detection of bacteria in endodontic samples by polymerase chain reaction assays and association with defined clinical signs in Italian patients. Oral Microbiol Immunol 2005: 20: 289-295.

56. Foschi F, Izard J, Sasaki H, Sambri V, Prati C, Mu“ ller R, Stashenko P. Treponema denticola in disseminating endodontic infections. J Dent Res 2006: 85: 761-765.

57. Fraser CM, Rappuoli R. Application of microbial genomic science to advanced therapeutics. Annu Rev Med 2005: 56: 459-474.

58. Fredericks DN, Relman DA. Sequence-based identification of microbial pathogens: a reconsideration of Koch's postulates. Clin Microbiol Rev 1996: 9: 18-33.

59. Gatti JJ, Dobeck JM, Smith C, White RR, Socransky SS, Skobe Z. Bacteria of asymptomatic periradicular endodontic lesions identified by DNA-DNA hybridization. Endod Dent Traumatol 2000: 16: 197-204.

60. Genco RJ, Ho AW, Grossi SG, Dunford RG, Tedesco LA. Relationship of stress, distress and inadequate coping behaviors to periodontal disease. J Periodontol 1999: 70: 711-723.

61. Gersdorf H, Meissner A, Pelz K, Krekeler G, Gobel UB. Identification of Bacteroides forsythus in subgingival plaque from patients with advanced periodontitis. J Clin Microbiol 1993: 31: 941-946. 
62. Gmur R, Guggenheim B. Monoclonal antibodies for the detection of "periodontopathic" bacteria. Arch Oral Biol 1990: 35(Suppl.): 145S-151S.

63. Gmur R, Marinello CP, Guggenheim B. Periodontitis associated bacteria in supragingival plaque of dental hygienists: stability of carrier state and clinical development. Eur J Oral Sci 1999: 107: 225-228.

64. Gmur R, Strub JR, Guggenheim B. Prevalence of Bacteroides forsythus and Bacteroides gingivalis in subgingival plaque of prosthodontically treated patients on short recall. J Periodontal Res 1989: 24: 113-120.

65. Gmur R, Wyss C, Xue Y, Thurnheer T, Guggenheim B. Gingival crevice microbiota from Chinese patients with gingivitis or necrotizing ulcerative gingivitis. Eur J Oral Sci 2004: 112: 33-41.

66. Goncalves LdeS, Ferreira SM, Silva A Jr, Villoria GE, Costinha LH, Souto R, Uzeda MD, Colombo AP. Association of T CD4 lymphocyte levels and subgingival microbiota of chronic periodontitis in HIV-infected Brazilians under HAART. Oral Surg Oral Med Oral Pathol Oral Radiol Endod 2004: 97: 196-203.

67. Goodson JM, Tanner A. Antibiotic resistance of the subgingival microbiota following local tetracycline therapy. Oral Microbiol Immunol 1992: 7: 113-117.

68. Goodson JM, Tanner A, McArdle S, Dix K, Watanabe SM. Multicenter evaluation of tetracycline fiber therapy. III. Microbiological response. J Periodontal Res 1991: 26: $440-451$.

69. Gosling PT, Gemmell E, Carter CL, Bird PS, Seymour GJ. Immunohistological analysis of Tannerella forsythiainduced lesions in a murine model. Oral Microbiol Immunol 2005: 20: 25-30.

70. Graber JR, Leadbetter JR, Breznak JA. Description of Treponema azotonutricium sp. nov. and Treponema primitia sp. nov., the first spirochetes isolated from termite guts. Appl Environ Microbiol 2004: 70: 1315-1320.

71. Grenier D. Characterization of the trypsin-like activity of Bacteroides forsythus. Microbiology 1995: 141: 921-926.

72. Grossi SG, Genco RJ, Machtei EE, Ho AW, Koch G, Dunford R, Zambon JJ, Hausmann E. Assessment of risk for periodontal disease. II. Risk indicators for alveolar bone loss. J Periodontol 1995: 66: 23-29.

73. Grossi SG, Zambon JJ, Ho AW, Koch G, Dunford RG, Machtei EE, Norderyd OM, Genco RJ. Assessment of risk for periodontal disease. I. Risk indicators for attachment loss. J Periodontol 1994: 65: 260-267.

74. Gunaratnam M, Smith GL, Socransky SS, Smith CM, Haffajee AD. Enumeration of subgingival species on primary isolation plates using colony lifts. Oral Microbiol Immunol 1992: 7: 14-18.

75. Gunsolley JC, Chinchilli VN, Savitt ED, Killoy W, Darack AP, Christersson LA, Fransson CF, Dunford RG, Zambon JJ. Analysis of site specific periodontal bacteria sampling schemes. J Periodontol 1992: 63: 507-514.

76. Haffajee AD, Cugini MA, Dibart S, Smith C, Kent RL Jr, Socransky SS. The effect of SRP on the clinical and microbiological parameters of periodontal diseases. J Clin Periodontol 1997: 24: 324-334. 
77. Haffajee AD, Cugini MA, Tanner A, Pollack RP, Smith C, Kent RL Jr, Socransky SS. Subgingival microbiota in healthy, well-maintained elder and periodontitis subjects. J Clin Periodontol 1998: 25: 346-353.

78. Haffajee AD, Socransky SS. Microbial etiological agents of destructive periodontal diseases. Periodontol 2000 1994: 5: 78-111.

79. Haffajee AD, Socransky SS. Relationship of cigarette smoking to the subgingival microbiota. J Clin Periodontol 2001: 28: 377-388.

80. Haffajee AD, Socransky SS, Dibart S, Kent RL Jr. Response to periodontal therapy in patients with high or low levels of P. gingivalis, $P$. intermedia, P. nigrescens and B. forsythus. J Clin Periodontol 1996: 23: 336-345.

81. Haffajee AD, Socransky SS, Dzink JL, Taubman MA, Ebersole JL. Clinical, microbiological and immunological features of subjects with refractory periodontal diseases. J Clin Periodontol 1988: 15: 390-398.

82. Haffajee AD, Socransky SS, Dzink JL, Taubman MA, Ebersole JL, Smith DJ. Clinical, microbiological and immunological features of subjects with destructive periodontal diseases. J Clin Periodontol 1988: 15: 240-246.

83. Haffajee AD, Socransky SS, Smith C, Dibart S. The use of DNA probes to examine the distribution of subgingival species in subjects with different levels of periodontal destruction. J Clin Periodontol 1992: 19: 84-91.

84. Hamlet S, Ellwood R, Cullinan M, Worthington H, Palmer J, Bird P, Narayanan D, Davies R, Seymour G. Persistent colonization with Tannerella forsythensis and loss of attachment in adolescents. J Dent Res 2004: 83: 232-235.

85. Haraszthy VI, Zambon JJ, Trevisan M, Zeid M, Genco RJ. Identification of periodontal pathogens in atheromatous plaques. J Periodontol 2000: 71: 1554-1560.

86. Harris JI, Russell RR, Curtis MA, duse-Opoku J, Taylor JJ. Molecular mediators of Porphyromonas gingivalisinduced T-cell apoptosis. Oral Microbiol Immunol 2002: 17: 224-230.

87. Hasebe A, Yoshimura A, Into T, Kataoka H, Tanaka S, Arakawa S, Ishikura H, Golenbock DT, Sugaya T, Tsuchida N, Kawanami M, Hara Y, Shibata K. Biological activities of Bacteroides forsythus lipoproteins and their possible pathological roles in periodontal disease. Infect Immun 2004: 72: 1318-1325.

88. Heitz-Mayfield L, Tonetti MS, Cortellini P, Lang NP. Microbial colonization patterns predict the outcomes of surgical treatment of intrabony defects. J Clin Periodontol 2006: 33: 62-68.

89. Herrera D, Roldan S, Gonzalez I, Sanz M. The periodontal abscess (I). Clinical and microbiological findings. J Clin Periodontol 2000: 27: 387-394.

90. Higuchi N, Murakami Y, Moriguchi K, Ohno N, Nakamura H, Yoshimura F. Localization of major, high molecular weight proteins in Bacteroides forsythus. Microbiol Immunol 2000: 44: 777-780.

91. Holt SC, Ebersole JL. Porphyromonas gingivalis, Treponema denticola, and Tannerella forsythia: the "red complex", a prototype polybacterial pathogenic consortium in periodontitis. Periodontol 2000 2005: 38: 72-122. 
92. Honma K, Kuramitsu HK, Genco RJ, Sharma A. Development of a gene inactivation system for Bacteroides forsythus: construction and characterization of a BspA mutant. Infect Immun 2001: 69: 4686-4690.

93. Huang Y, Umeda M, Takeuchi Y, Ishizuka M, Yano-Higuchi K, Ishikawa I. Distribution of Bacteroides forsythus genotypes in a Japanese periodontitis population. Oral Microbiol Immunol 2003: 18: 208-214.

94. Hudspeth MK, Hunt GS, Maiden MF, Citron DM, Goldstein EJ. Characterization of Bacteroides forsythus strains from cat and dog bite wounds in humans and comparison with monkey and human oral strains. J Clin Microbiol 1999: 37: 2003-2006.

95. Hugenholtz P, Pitulle C, Hershberger KL, Pace NR. Novel division level bacterial diversity in a Yellowstone hot spring. J Bacteriol 1998: 180: 366-376.

96. Hugenholtz P, Tyson GW, Webb RI, Wagner AM, Blackall LL. Investigation of candidate division TM7, a recently recognized major lineage of the domain Bacteria with no known pure-culture representatives. Appl Environ Microbiol 2001: 67: 411-419.

97. Hughes CV, Malki G, Loo CY, Tanner AC, Ganeshkumar N. Cloning and expression of alpha-D-glucosidase and $\mathrm{N}$-acetyl-beta-glucosaminidase from the periodontal pathogen, Tannerella forsythensis (Bacteroides forsythus). Oral Microbiol Immunol 2003: 18: 309-312.

98. Hultin M, Gustafsson A, Hallstrom H, Johansson LA, Ekfeldt A, Klinge B. Microbiological findings and host response in patients with peri-implantitis. Clin Oral Implants Res 2002: 13: 349-358.

99. Ikegami A, Honma K, Sharma A, Kuramitsu HK. Multiple functions of the leucinerich repeat protein LrrA of Treponema denticola. Infect Immun 2004: 72: 4619-4627.

100. Inagaki S, Kuramitsu HK, Sharma A. Contact-dependent regulation of a Tannerella forsythia virulence factor, BspA, in biofilms. FEMS Microbiol Lett 2005: 249: 291-296.

101. Ishihara K, Nabuchi A, Ito R, Miyachi K, Kuramitsu HK, Okuda K. Correlation between detection rates of periodontopathic bacterial DNA in coronary stenotic artery plaque [corrected] and in dental plaque samples. J Clin Microbiol 2004: 42: 1313-1315.

102. Ishikura H, Arakawa S, Nakajima T, Tsuchida N, Ishikawa I. Cloning of the Tannerella forsythensis (Bacteroides forsythus) siaHI gene and purification of the sialidase enzyme. J Med Microbiol 2003: 52: 1101-1107.

103. Iwai T, Inoue $Y$, Umeda M, Huang Y, Kurihara N, Koike M, Ishikawa I. Oral bacteria in the occluded arteries of patients with Buerger disease. J Vasc Surg 2005: 42: 107-115.

104. Izard J, Samsonoff WA, Limberger RJ. Cytoplasmic filament-deficient mutant of Treponema denticola has pleiotropic defects. J Bacteriol 2001: 183: 1078-1084.

105. Jacobs D. A descriptive microbiological study of periapical infection. Masters Thesis. Boston University Medical Center Alumni Library, Boston, MA; 1980. 
106. Jervoe-Storm PM, Koltzscher M, Falk W, Dorfler A, Jepsen S. Comparison of culture and real-time PCR for detection and quantification of five putative periodontopathogenic bacteria in subgingival plaque samples. J Clin Periodontol 2005: 32: 778-783.

107. Jung IY, Choi B, Kum KY, Yoo YJ, Yoon TC, Lee SJ, Lee CY. Identification of oral spirochetes at the species level and their association with other bacteria in endodontic infections. Oral Surg Oral Med Oral Pathol Oral Radiol Endod 2001: 92: 329-334.

108. Kajava AV. Structural diversity of leucine-rich repeat proteins. J Mol Biol 1998 : 277: 519-527.

109. Kalapos MP. Methylglyoxal in living organisms: chemistry, biochemistry, toxicology and biological implications. Toxicol Lett 1999: 110: 145-175.

110. Kamma JJ, Amanti-Kipioti A, Nakou M, Mitsis FJ. Profile of subgingival microbiota in children with mixed dentition. Oral Microbiol Immunol 2000: 15: 103-111.

111. Kamma JJ, Amanti-Kipioti A, Nakou M, Mitsis FJ. Profile of subgingival microbiota in children with primary dentition. J Periodontal Res 2000: 35: 33-41.

112. Kamma JJ, Nakou M, Baehni PC. Clinical and microbiological characteristics of smokers with early onset periodontitis. J Periodontal Res 1999: 34: 25-33.

113. Kamma JJ, Nakou M, Manti FA. Microbiota of rapidly progressive periodontitis lesions in association with clinical parameters. J Periodontol 1994: 65: 1073-1078.

114. Kamma JJ, Nakou M, Manti FA. Predominant microflora of severe, moderate and minimal periodontal lesions in young adults with rapidly progressive periodontitis. J Periodontal Res 1995: 30: 66-72.

115. Kamma JJ, Nakou M, Persson RG. Association of early onset periodontitis microbiota with aspartate aminotransferase activity in gingival crevicular fluid. J Clin Periodontol 2001: 28: 1096-1105.

116. Kashket S, Maiden MF, Haffajee AD, Kashket ER. Accumulation of methylglyoxal in the gingival crevicular fluid of chronic periodontitis patients. J Clin Periodontol 2003: 30: 364-367.

117. Kasuga Y, Ishihara K, Okuda K. Significance of detection of Porphyromonas gingivalis, Bacteroides forsythus and Treponema denticola in periodontal pockets. Bull Tokyo Dent Coll 2000: 41: 109-117.

118. Kimura S, Ooshima T, Takiguchi M, Sasaki Y, Amano A, Morisaki I, Hamada S. Periodontopathic bacterial infection in childhood. J Periodontol 2002: 73: $20-26$.

119. Klein MI, Goncalves RB. Detection of Tannerella forsythensis (Bacteroides forsythus) and Porphyromonas gingivalis by polymerase chain reaction in subjects with different periodontal status. J Periodontol 2003: 74: 798-802.

120. Kobe B, Kajava AV. The leucine-rich repeat as a protein recognition motif. Curr Opin Struct Biol 2001: 11: 725-732.

121. Kolenbrander PE, Andersen RN, Blehert DS, Egland PG, Foster JS, Palmer RJ Jr. Communication among oral bacteria. Microbiol Mol Biol Rev 2002: 66: 486-505. 
122. Kuboniwa M, Amano A, Kimura KR, Sekine S, Kato S, Yamamoto Y, Okahashi N, Iida T, Shizukuishi S. Quantitative detection of periodontal pathogens using real-time polymerase chain reaction with TaqMan probes. Oral Microbiol Immunol 2004: 19: 168-176.

123. Kumar PS, Griffen AL, Barton JA, Paster BJ, Moeschberger ML, Leys EJ. New bacterial species associated with chronic periodontitis. J Dent Res 2003: 82: 338-344.

124. Kumar PS, Griffen AL, Moeschberger ML, Leys EJ. Identification of candidate periodontal pathogens and beneficial species by quantitative $16 \mathrm{~S}$ clonal analysis. J Clin Microbiol 2005: 43: 3944-3955.

125. Lai CH, Listgarten MA, Shirakawa M, Slots J. Bacteroides forsythus in adult gingivitis and periodontitis. Oral Microbiol Immunol 1987: 2: 152-157.

126. Lakhssassi N, Elhajoui N, Lodter JP, Pineill JL, Sixou M. Antimicrobial susceptibility variation of 50 anaerobic periopathogens in aggressive periodontitis: an interindividual variability study. Oral Microbiol Immunol 2005: 20: 244-252.

127. Lau L, Sanz M, Herrera D, Morillo JM, Martin C, Silva A. Quantitative real-time polymerase chain reaction versus culture: a comparison between two methods for the detection and quantification of Actinobacillus actinomycetemcomitans, Porphyromonas gingivalis and Tannerella forsythensis in subgingival plaque samples. J Clin Periodontol 2004: 31: 1061-1069.

128. Lee JW, Choi BK, Yoo YJ, Choi SH, Cho KS, Chai JK, Kim CK. Distribution of periodontal pathogens in Korean aggressive periodontitis. J Periodontol 2003: 74: 1329-1335.

129. Lee KH, Maiden MF, Tanner AC, Weber HP. Microbiota of successful osseointegrated dental implants. J Periodontol 1999: 70: 131-138.

130. Lee KH, Tanner AC, Maiden MF, Weber HP. Pre- and post-implantation microbiota of the tongue, teeth, and newly placed implants. J Clin Periodontol 1999: 26: 822-832.

131. Lepp PW, Brinig MM, Ouverney CC, Palm K, Armitage GC, Relman DA. Methanogenic Archaea and human periodontal disease. Proc Natl Acad Sci U S A 2004: 101: 6176-6181.

132. Leys EJ, Lyons SR, Moeschberger ML, Rumpf RW, Griffen AL. Association of Bacteroides forsythus and a novel Bacteroides phylotype with periodontitis. J Clin Microbiol 2002: 40: 821-825.

133. Listgarten MA, Lai CH. Comparative microbiological characteristics of failing implants and periodontally diseased teeth. J Periodontol 1999: 70: 431-437.

134. Lo Bue AM, Blandino G, Milazzo I, Pasquantonio G, Speciale A, Nicoletti G. Antibacterial activity and postantibiotic effect of flurithromycin compared with other macrolides and penicillins against periodontal pathogens. J Chemother 2001: 13: 255-259.

135. Lo Bue AM, Nicoletti G, Toscano MA, Rossetti B, Cali G, Condorelli F. Porphyromonas gingivalis prevalence related to other micro-organisms in adult refractory periodontitis. New Microbiol 1999: 22: 209-218. 
136. Loesche WJ. The identification of bacteria associated with periodontal disease and dental caries by enzymatic methods. Oral Microbiol Immunol 1986: 1: 65-72.

137. Loesche WJ, Lopatin DE, Giordano J, Alcoforado G, Hujoel P. Comparison of the benzoyl-DL-arginine-naphthylamide (BANA) test, DNA probes, and immunological reagents for ability to detect anaerobic periodontal infections due to Porphyromonas gingivalis, Treponema denticola, and Bacteroides forsythus. J Clin Microbiol 1992: 30: 427-433.

138. Lotufo RF, Flynn J, Chen C, Slots J. Molecular detection of Bacteroides forsythus in human periodontitis. Oral Microbiol Immunol 1994: 9: 154-160.

139. Lotufo RF, Pannuti CM, Saraiva MC. Bacteroides forsythus: sensitivity to antimicrobial agents in samples from patients with periodontitis. Pesqui Odontol Bras 2001: 15: 47-50.

140. Lundgren T, Renvert S, Papapanou PN, Dahlen G. Subgingival microbial profile of Papillon-Lefe vre patients assessed by DNA-probes. J Clin Periodontol 1998: 25: 624-629.

141. Machtei EE, Dunford R, Hausmann E, Grossi SG, Powell J, Cummins D, Zambon JJ, Genco RJ. Longitudinal study of prognostic factors in established periodontitis patients. J Clin Periodontol 1997: 24: 102-109.

142. Machtei EE, Hausmann E, Dunford R, Grossi S, Ho A, Davis G, Chandler J, Zambon JJ, Genco RJ. Longitudinal study of predictive factors for periodontal disease and tooth loss. J Clin Periodontol 1999: 26: 374-380.

143. Maiden MF, Cohee P, Tanner AC. Proposal to conserve the adjectival form of the specific epithet in the reclassification of Bacteroides forsythus Tanner et al. 1986 to the genus Tannerella Sakamoto et al. 2002 as Tannerella forsythia corrig., gen. nov., comb. nov. Request for an Opinion. Int J Syst Evol Microbiol 2003: 53: 2111-2112.

144. Maiden MF, Pham C, Kashket S. Glucose toxicity effect and accumulation of methylglyoxal by the periodontal anaerobe Bacteroides forsythus. Anaerobe 2004: 10: 27-32.

145. Maiden MF, Tanner A, Macuch PJ. Rapid characterization of periodontal bacterial isolates by using fluorogenic substrate tests. J Clin Microbiol 1996: 34: 376-384.

146. Mellanen L, Sorsa T, Lahdevirta J, Helenius M, Kari K, Meurman JH. Salivary albumin, total protein, IgA, IgG and IgM concentrations and occurrence of some periodontopathogens in HIV-infected patients: a 2-year follow-up study. J Oral Pathol Med 2001: 30: 553-559.

147. Michalowicz BS, Aeppli D, Virag JG, Klump DG, Hinrichs JE, Segal NL, Bouchard TJ Jr, Pihlstrom BL. Periodontal findings in adult twins. J Periodontol 1991: 62: 293-299.

148. Milazzo I, Blandino G, Caccamo F, Musumeci R, Nicoletti G, Speciale A. Faropenem, a new oral penem: antibacterial activity against selected anaerobic and fastidious periodontal isolates. J Antimicrob Chemother 2003: 51: 721-725. 
149. Milazzo I, Blandino G, Musumeci R, Nicoletti G, Lo Bue AM, Speciale A. Antibacterial activity of moxifloxacin against periodontal anaerobic pathogens involved in systemic infections. Int J Antimicrob Agents 2002: 20: 451-456.

150. Moncla BJ, Motley ST, Braham P, Ewing L, Adams TH, Vermeulen NM. Use of synthetic oligonucleotide DNA probes for identification and direct detection of Bacteroides forsythus in plaque samples. J Clin Microbiol 1991: 29: 2158-2162.

151. Moore LV, Moore WE, Cato EP, Smibert RM, Burmeister JA, Best AM, Ranney RR. Bacteriology of human gingivitis. J Dent Res 1987: 66: 989-995.

152. Moore WE. Microbiology of periodontal disease. J Periodontal Res 1987: 22: 335-341.

153. Moore WE, Moore LH, Ranney RR, Smibert RM, Burmeister JA, Schenkein HA. The microflora of periodontal sites showing active destructive progression. $J$ Clin Periodontol 1991: 18: 729-739.

154. Moore WE, Moore LV. The bacteria of periodontal diseases. Periodontol 2000 1994: 5: 66-77.

155. Moriguchi K, Higuchi N, Murakami Y, Yoshimura F, Nakamura H, Ohno N. A morphological and immunolabeling study of freeze-substituted Bacteroides forsythus. Biotech Histochem 2003: 78: 129-133.

156. Mullally BH, Dace B, Shelburne CE, Wolff LF, Coulter WA. Prevalence of periodontal pathogens in localized and generalized forms of early-onset periodontitis. J Periodontal Res 2000: 35: 232-241.

157. MunsonMA,Pitt-Ford T,ChongB,WeightmanA,WadeWG. Molecular and cultural analysis of the microflora associated with endodontic infections. J Dent Res 2002: 81: 761-766.

158. Murakami Y, Higuchi N, Nakamura H, Yoshimura F, Oppenheim FG. Bacteroides forsythus hemagglutinin is inhibited by $\mathrm{N}$-acetylneuraminyllactose. Oral Microbiol Immunol 2002: 17: 125-128.

159. Okada M, Hayashi F, Nagasaka N. PCR detection of 5 putative periodontal pathogens in dental plaque samples from children 2 to 12 years of age. J Clin Periodontol 2001: 28: 576-582.

160. Okada M, Hayashi F, Soda Y, Zhong X, Miura K, Kozai K. Intra-familial distribution of nine putative periodontopathogens in dental plaque samples analyzed by PCR. J Oral Sci 2004: 46: 149-156.

161. Okuda K. Bacteriological diagnosis of periodontal disease. Bull Tokyo Dent Coll 1994: 35: 107-119.

162. Palmer RJ Jr, Kazmerzak K, Hansen MC, Kolenbrander PE. Mutualism versus independence: strategies of mixedspecies oral biofilms in vitro using saliva as the sole nutrient source. Infect Immun 2001: 69: 5794-5804.

163. Papapanou PN, Baelum V, Luan WM, Madianos PN, Chen X, Fejerskov O, Dahlen G. Subgingival microbiota in adult Chinese: prevalence and relation to periodontal disease progression. J Periodontol 1997: 68: 651-666.

164. Papapanou PN, Madianos PN, Dahlen G, Sandros J. “Checkerboard” versus culture: a comparison between two methods for identification of subgingival microbiota. Eur J Oral Sci 1997: 105: 389-396. 
165. Papapanou PN, Neiderud AM, Papadimitriou A, Sandros J, Dahlen G. "Checkerboard" assessments of periodontal microbiota and serum antibody responses: a case-control study. J Periodontol 2000: 71: 885-897.

166. Paster BJ, Bartoszyk IM, Dewhirst FE. Identification of oral streptococci using PCR-based, reverse-capture, checkerboard hybridization. Methods Cell Sci 1998: 20: 223-231.

167. Paster BJ, Boches SK, Galvin JL, Ericson RE, Lau CN, Levanos VA, Sahasrabudhe A, Dewhirst FE. Bacterial diversity in human subgingival plaque. J Bacteriol 2001: 183: 3770-3783.

168. Paster BJ, Dewhirst FE, Olsen I, Fraser GJ. Phylogeny of Bacteroides, Prevotella, and Porphyromonas spp. and related bacteria. J Bacteriol 1994: 176: 725-732.

169. Reid HI, Riggio MP. Identification and nucleotide sequence of the heat shock protein 60 (GroEL) gene of Bacteroides forsythus. DNA Seq 1998: 9: 359-364.

170. Relman DA. New technologies, human-microbe interactions, and the search for previously unrecognized pathogens. J Infect Dis 2002: 186(Suppl. 2): S254-S258.

171. Rodrigues RM, Goncalves C, Souto R, Feres-Filho EJ, Uzeda M, Colombo AP. Antibiotic resistance profile of the subgingival microbiota following systemic or local tetracycline therapy. J Clin Periodontol 2004: 31: 420-427.

172. Rovaldi CR, Pievsky A, Sole NA, Friden PM, Rothstein DM, Spacciapoli P. Photoactive porphyrin derivative with broad-spectrum activity against oral pathogens in vitro. Antimicrob Agents Chemother 2000: 44: 3364-3367.

173. Rudiger S, Petersilka G, Flemmig TF. Combined systemic and local antimicrobial therapy of periodontal disease in Papillon-Lefe vre syndrome. A report of 4 cases. J Clin Periodontol 1999: 26: 847-854.

174. Rudney JD, Chen R, Sedgewick GJ. Intracellular Actinobacillus actinomycetemcomitans and Porphyromonas gingivalis in buccal epithelial cells collected from human subjects. Infect Immun 2001: 69: 2700-2707.

175. Rudney JD, Chen R, Sedgewick GJ. Actinobacillus actinomycetemcomitans, Porphyromonas gingivalis, and Tannerella forsythensis are components of a polymicrobial intracellular flora within human buccal cells. J Dent Res 2005: 84: 59-63.

176. Rupf S, Kannengiesser S, Merte K, Pfister W, Sigusch B, Eschrich K. Comparison of profiles of key periodontal pathogens in periodontium and endodontium. Endod Dent Traumatol 2000: 16: 269-275.

177. Sabet M, Lee SW, Nauman RK, Sims T, Um HS. The surface (S-) layer is a virulence factor of Bacteroides forsythus. Microbiology 2003: 149: 3617-3627.

178. Saito T, Ishihara K, Kato T, Okuda K. Cloning, expression, and sequencing of a protease gene from Bacteroides forsythus ATCC 43037 in Escherichia coli. Infect Immun 1997: 65: 4888-4891.

179. Sakamoto M, Suzuki M, Umeda M, Ishikawa I, Benno Y. Reclassification of Bacteroides forsythus (Tanner et al. 1986) as Tannerella forsythensis corrig., gen. nov., comb. nov. Int J Syst Evol Microbiol 2002: 52: 841-849. 
180. Sakamoto M, Takeuchi Y, Umeda M, Ishikawa I, Benno Y. Rapid detection and quantification of five periodontopathic bacteria by real-time PCR. Microbiol Immunol 2001: 45: 39-44.

181. Sakamoto M, Umeda M, Benno Y. Molecular analysis of humanoral microbiota. J Periodontal Res 2005: 40: 277-285.

182. Sakamoto M, Umeda M, Ishikawa I, Benno Y. Comparison of the oral bacterial flora in saliva from a healthy subject and two periodontitis patients by sequence analysis of 16S rDNA libraries. Microbiol Immunol 2000: 44: 643-652.

183. Salvador SL, Grisi MF, Romanelli RG, Silva Netto CR, Schork NM, Bretz WA. Similarities of periodontal clinical and microbiological parameters in motherchild pairs. Braz Dent J 1997: 8: 99-104.

184. Sanz M, Lau L, Herrera D, Morillo JM, Silva A. Methods of detection of Actinobacillus actinomycetemcomitans, Porphyromonas gingivalis and Tannerella forsythensis in periodontal microbiology, with special emphasis on advanced molecular techniques: a review. J Clin Periodontol 2004: 31 : 1034-1047.

185. Sasaki H, Hou L, Belani A, Wang CY, Uchiyama T, Muller R, Stashenko P. IL-10, but not IL-4, suppresses infectionstimulated bone resorption in vivo. J Immunol 2000: 165: 3626-3630.

186. Schmitt-Wagner D, Friedrich MW, Wagner B, Brune A. Phylogenetic diversity, abundance, and axial distribution of bacteria in the intestinal tract of two soil-feeding termites (Cubitermes spp.). Appl Environ Microbiol 2003: 69: 6007-6017.

187. Seida K, Saito A, Yamada S, Ishihara K, Naito Y, Okuda K. A sensitive enzymatic method (SK-013) for detection of Treponema denticola, Porphyromonas gingivalis and Bacteroides forsythus in subgingival plaque samples.J Periodontal Res 1992: 27: 86-91.

188. Shah HN, Collins MD. Proposal for reclassification of Bacteroides asaccharolyticus, Bacteroides gingivalis and Bacteroides endodontalis in a new genus, Porphyromonas. Int J Syst Bacteriol 1988: 38: 128-131.

189. Shah HN, Collins DM. Prevotella, a new genus to include Bacteroides melaninogenicus and related species formerly classified in the genus Bacteroides. Int J Syst Bacteriol 1990: 40: 205-208.

190. Sharma A, Inagaki S, Honma K, Sfintescu C, Baker PJ, Evans RT. Tannerella forsythia-induced alveolar bone loss in mice involves leucine-rich-repeat BspA protein. J Dent Res 2005: 84: 462-467.

191. Sharma A, Sojar HT, Glurich I, Honma K, Kuramitsu HK, Genco RJ. Cloning, expression, and sequencing of a cell surface antigen containing a leucine-rich repeat motif from Bacteroides forsythus ATCC 43037. Infect Immun 1998: 66: 5703-5710.

192. Shelburne CE, Prabhu A, Gleason RM, Mullally BH, Coulter WA. Quantitation of Bacteroides forsythus in subgingival plaque comparison of immunoassay and quantitative polymerase chain reaction. J Microbiol Methods 2000: 39: 97-107. 
193. Shiloah J, Patters MR, Dean JW III, Bland P, Toledo G. The prevalence of Actinobacillus actinomycetemcomitans, Porphyromonas gingivalis, and Bacteroides forsythus in humans 1 year after 4 randomized treatment modalities. J Periodontol 1998: 69: 1364-1372.

194. Shinzato N, Muramatsu M, Matsui T, Watanabe Y. Molecular phylogenetic diversity of the bacterial community in the gut of the termite Coptotermes formosanus. Biosci Biotechnol Biochem 2005: 69: 1145-1155.

195. Siqueira JF Jr, Rocas IN. Bacteroides forsythus in primary endodontic infections as detected by nested PCR. J Endod 2003: 29: 390-393.

196. Siqueira JF Jr, Rocas IN. Exploiting molecular methods to explore endodontic infections: Part 1-current molecular technologies for microbiological diagnosis. J Endod 2005: 31: 411-423.

197. Siqueira JF, Rocas IN, De UM, Colombo AP, Santos KR. Comparison of 16 S rDNAbased PCR and checkerboard DNA-DNA hybridisation for detection of selected endodontic pathogens. J Med Microbiol 2002: 51: 1090-1096.

198. Siqueira JF Jr, Rocas IN, Souto R, De UM, Colombo AP. Checkerboard DNA-DNA hybridization analysis of endodontic infections. Oral Surg Oral Med Oral Pathol Oral Radiol Endod 2000: 89: 744-748.

199. Slots J. Detection of colonies of Bacteroides gingivalis by a rapid fluorescence assay for trypsin-like activity. Oral Microbiol Immunol 1987: 2: 139-141.

200. Slots J. Herpesviruses in periodontal diseases. Periodontol 2000 2005: 38: 33-62.

201. Slots J, Ashimoto A, Flynn MJ, Li G, Chen C. Detection of putative periodontal pathogens in subgingival specimens by $16 \mathrm{~S}$ ribosomal DNA amplification with the polymerase chain reaction. Clin Infect Dis 1995: 20(Suppl. 2): S304-S307.

202. Socransky SS, Haffajee AD. Periodontal microbial ecology. Periodontol 2000 2005: 38: 135-187.

203. Socransky SS, Haffajee AD. Microbiological risk factors for destructive periodontal diseases. In: Bader JD, editor. Risk assessment in dentistry. Chapel Hill, NC: University of North Carolina Dental Ecology, 1990: 79-90.

204. Socransky SS, Haffajee AD. Effect of therapy on periodontal infections. $J$ Periodontol 1993: 64(8 Suppl.): 754-759.

205. Socransky SS, Haffajee AD, Cugini MA, Smith C, Kent RL Jr. Microbial complexes in subgingival plaque. J Clin Periodontol 1998: 25: 134-144.

206. Socransky SS, Haffajee AD, Smith C, Duff GW. Microbiological parameters associated with IL-1 gene polymorphisms in periodontitis patients. J Clin Periodontol 2000: 27: 810-818.

207. Socransky SS, Smith C, Haffajee AD. Subgingival microbial profiles in refractory periodontal disease. J Clin Periodontol 2002: 29: 260-268.

208. Socransky SS, Smith C, Martin L, Paster BJ, Dewhirst FE, Levin AE. “Checkerboard" DNA-DNA hybridization. Biotechniques 1994: 17: 788-792.

209. Soukos NS, Som S, Abernethy AD, Ruggiero K, Dunham J, Lee C, Doukas AG, Goodson JM. Phototargeting oral black-pigmented bacteria. Antimicrob Agents Chemother 2005: 49: 1391-1396. 
210. Spacciapoli P, Buxton D, Rothstein D, Friden P. Antimicrobial activity of silver nitrate against periodontal pathogens. J Periodontal Res 2001: 36: 108-113.

211. Suda R, Kobayashi M, Nanba R, Iwamaru M, Hayashi Y, Lai CH, Hasegawa K. Possible periodontal pathogens associated with clinical symptoms of periodontal disease in Japanese high school students. J Periodontol 2004: 75: 1084-1089.

212. Sunde PT, Olsen I, Gobel UB, Theegarten D, Winter S, Debelian GJ, Tronstad L, Moter A. Fluorescence in situ hybridization (FISH) for direct visualization of bacteria in periapical lesions of asymptomatic root-filled teeth. Microbiology 2003: 149: 1095-1102.

213. Sunde PT, Tronstad L, Eribe ER, Lind PO, Olsen I. Assessment of periradicular microbiota by DNA-DNA hybridization. Endod Dent Traumatol 2000: 16: 191-196.

214. Suzuki N, Yoshida A, Saito T, Kawada M, Nakano Y. Quantitative microbiological study of subgingival plaque by real-time PCR shows correlation between levels of Tannerella forsythensis and Fusobacterium spp. J Clin Microbiol 2004: 42: 2255-2257.

215. Takamatsu N, Yano K, He T, Umeda M, Ishikawa I. Effect of initial periodontal therapy on the frequency of detecting Bacteroides forsythus, Porphyromonas gingivalis, and Actinobacillus actinomycetemcomitans. J Periodontol 1999: 70: 574-580.

216. Takemoto T, Kurihara H, Dahlen G. Characterization of Bacteroides forsythus isolates. J Clin Microbiol 1997: 35: 1378-1381.

217. Takeuchi Y, Umeda M, Ishizuka M, Huang Y, Ishikawa I. Prevalence of periodontopathic bacteria in aggressive periodontitis patients in a Japanese population. J Periodontol 2003: 74: 1460-1469.

218. Tamura K, Nakano K, Hayashibara T, Nomura R, Fujita K, Shintani S, Ooshima T. Distribution of 10 periodontal bacteria in saliva samples from Japanese children and their mothers. Arch Oral Biol 2006: 51: 371-377. Epub 2005 Nov 2.

219. Tanaka M, Yamamoto Y, Kuboniwa M, Nonaka A, Nishida N, Maeda K, Kataoka $\mathrm{K}$, Nagata H, Shizukuishi S. Contribution of periodontal pathogens on tongue dorsa analyzed with real-time PCR to oral malodor. Microbes Infect 2004: 6: 1078-1083.

220. Tanner A. Is the specific plaque hypothesis still tenable? In: Guggenheim B, ed. Proceedings of the European Research Group for Oral Biology Conference, "Periodontology Today". Basel: S Karger AG, 1988: 123-131.

221. Tanner A, Bouldin H. The microbiota of early periodontitis lesions in adults. J Clin Periodontol 1989: 16: 467-471.

222. Tanner A, Kent R, Maiden MF, Taubman MA. Clinical, microbiological and immunological profile of healthy, gingivitis and putative active periodontal subjects. J Periodontal Res 1996: 31: 195-204.

223. Tanner A, Maiden MF, Lee K, Shulman LB, Weber HP. Dental implant infections. Clin Infect Dis 1997: 25(Suppl. 2): S213-S217. 
224. Tanner A, Maiden MF, Paster BJ, Dewhirst FE. The impact of 16 S ribosomal RNA-based phylogeny on the taxonomy of oral bacteria. Periodontol 2000 1994: 5: 26-51.

225. Tanner AC, Haffer C, Bratthall GT, Visconti RA, Socransky SS. A study of the bacteria associated with advancing periodontitis in man. J Clin Periodontol 1979: 6: 278-307.

226. Tanner AC, Maiden MF, Zambon JJ, Thoren GS, Kent RL Jr. Rapid chair-side DNA probe assay of Bacteroides forsythus and Porphyromonas gingivalis. J Periodontal Res 1998: 33: 105-117.

227. Tanner AC, Milgrom PM, Kent R Jr, Mokeem SA, Page RC, Liao SI, Riedy CA, Bruss JB. Similarity of the oral microbiota of pre-school children with that of their caregivers in a population-based study. Oral Microbiol Immunol 2002: 17: 379-387.

228. Tanner AC, Paster BJ, Lu SC, Kanasi E, Kent R Jr, Van DT, Sonis ST. Subgingival and tongue microbiota during early periodontitis. J Dent Res 2006: 85: 318-323.

229. Tanner AC, Socransky SS, Goodson JM. Microbiota of periodontal pockets losing crestal alveolar bone. J Periodontal Res 1984: 19: 279-291.

230. Tanner AC, Strzempko MN, Belsky CA, McKinley GA. API ZYM and API An-Ident reactions of fastidious oral gramnegative species. J Clin Microbiol 1985: 22: 333-335.

231. Tanner ACR, Maiden MF, Macuch PJ, Murray LL, Kent RL Jr. Microbiota of health, gingivitis, and initial periodontitis. J Clin Periodontol 1998: 25: 85-98.

232. Tanner ACR, Listgarten MA, Ebersole JL, Strzempko MN. Bacteroides forsythus sp. nov., a slow growing fusiform Bacteroides sp. from the human oral cavity. Int J Syst Bacteriol 1986: 36: 213-221.

233. Tran SD, Rudney JD. Improved multiplex PCR using conserved and speciesspecific 16S rRNA gene primers for simultaneous detection of Actinobacillus actinomycetemcomitans, Bacteroides forsythus, and Porphyromonas gingivalis. J Clin Microbiol 1999: 37: 3504-3508.

234. Tran SD, Rudney JD, Sparks BS, Hodges JS. Persistent presence of Bacteroides forsythus as a risk factor for attachment loss in a population with low prevalence and severity of adult periodontitis. J Periodontol 2001: 72: 1-10.

235. Trevilatto PC, Tramontina VA, Machado MA, Goncalves RB, Sallum AW, Line SR. Clinical, genetic and microbiological findings in a Brazilian family with aggressive periodontitis. J Clin Periodontol 2002: 29: 233-239.

236. Tsai CY, Wolff LF, Germaine G, Hodges J. A rapid DNA probe test compared to culture methods for identification of subgingival plaque bacteria. J Clin Periodontol 2003: 30: 57-62.

237. Umeda M, Chen C, Bakker I, Contreras A, Morrison JL, Slots J. Risk indicators for harboring periodontal pathogens. J Periodontol 1998: 69: 1111-1118.

238. Umeda M, Miwa Z, Takeuchi Y, Ishizuka M, Huang Y, Noguchi K, Tanaka M, Takagi Y, ishikawa I. The distribution of periodontopathic bacteria among Japanese children and their parents. J Periodontal Res 2004: 39: 398-404. 
239. Umeda M, Tominaga Y, He T, Yano K, Watanabe H, Ishikawa I. Microbial flora in the acute phase of periodontitis and the effect of local administration of minocycline. J Periodontol 1996: 67: 422-427.

240. Van der Velden U, Varoufaki A, Hutter JW, Xu L, Timmerman MF, van Winkelhoff AJ, Loos BJ. Effect of smoking and periodontal treatment on the subgingival microflora. J Clin Periodontol 2003: 30: 603-610.

241. Van Horn KG, Smibert RM. Albumin requirement of Treponema denticola and Treponema vincentii. Can J Microbiol 1983: 29: 1141-1148.

242. van Winkelhoff AJ, Bosch-Tijhof CJ, Winkel EG, van der Reijden WA. Smoking affects the subgingival microflora in periodontitis. J Periodontol 2001: 72: 666-671.

243. van Winkelhoff AJ, Goene RJ, Benschop C, Folmer T. Early colonization of dental implants by putative periodontal pathogens in partially edentulous patients. Clin Oral Implants Res 2000: 11: 511-520.

244. Van Winkelhoff AJ, Herrera GD, Winkel EG, Lemijn-Kippuw N, VandenbrouckeGrauls CM, Sanz M. Antimicrobial resistance in the subgingival microflora in patients with adult periodontitis. A comparison between The Netherlands and Spain. J Clin Periodontol 2000: 27: 79-86.

245. van Winkelhoff AJ, Loos BG, van der Reijden WA, Van der Velden U.

Porphyromonas gingivalis, Bacteroides forsythus and other putative periodontal pathogens in subjects with and without periodontal destruction. J Clin Periodontol 2002: 29: 1023-1028.

246. van Winkelhoff AJ, Winkel EG, Barendregt D, Lemijn- Kippuw N, Stijne A, Van der Velden U. $\beta$-Lactamase producing bacteria in adult periodontitis. J Clin Periodontol 1997: 24: 538-543.

247. Vasel D, Sims TJ, Bainbridge B, Houston L, Darveau R, Page RC. Shared antigens of Porphyromonas gingivalis and Bacteroides forsythus. Oral Microbiol Immunol 1996: 11: 226-235.

248. Vesey PM, Kuramitsu HK. Genetic analysis of Treponema denticola ATCC 35405 biofilm formation. Microbiology 2004: 150: 2401-2407.

249. Vianna ME, Horz HP, Gomes BP, Conrads G. Microarrays complement culture methods for identification of bacteria in endodontic infections. Oral Microbiol Immunol 2005: 20: 253-258.

250. Vila-Campos MJ, Velasquez-Melendez G. Prevalence of putative periodontopathogens from periodontal patients and healthy subjects in Sao Paulo, SP, Brazil. Rev Inst Med Trop Sao Paulo 2002: 44: 1-5.

251. Villedieu A, Diaz-Torres ML, Hunt N, McNab R, Spratt DA, Wilson M, Mullaney P. Prevalence of tetracycline resistance genes in oral bacteria. Antimicrob Agents Chemother 2003: 47: 878-882.

252. Vingadassalom D, Kolb A, Mayer C, Rybkine T, Collatz E, Podglajen I. An unusual primary sigma factor in the Bacteroidetes phylum. Mol Microbiol 2005: 56: 888-902.

253. Walker CB, Karpinia K, Baehni P. Chemotherapeutics: antibiotics and other antimicrobials. Periodontol 2000 2004: 36: 146-165. 
254. Wecke J, Kersten T, Madela K, Moter A, Gobel UB, Friedmann A, Bernimoulin J. A novel technique for monitoring the development of bacterial biofilms in human periodontal pockets. FEMS Microbiol Lett 2000: 191: 95-101.

255. Werner-Felmayer G, Guggenheim B, Gmur R. Production and characterization of monoclonal antibodies against Bacteroides forsythus and Wolinella recta.J Dent Res 1988: 67: 548-553.

256. Winkel EG, van Winkelhoff AJ, Timmerman MF, Vangsted T, Van der Velden U. Effects of metronidazole in patients with "refractory" periodontitis associated with Bacteroides forsythus. J Clin Periodontol 1997: 24: 573-579.

257. Winkel EG, van Winkelhoff AJ, Van der Velden U. Additional clinical and microbiological effects of amoxicillin and metronidazole after initial periodontal therapy. J Clin Periodontol 1998: 25: 857-864.

258. Wong M, DiRienzo JM, Lai CH, Listgarten MA. Comparison of randomly cloned and whole genomic DNA probes for the detection of Porphyromonas gingivalis and Bacteroides forsythus. J Periodontal Res 1996: 31: 27-35.

259. Wood N, Johnson RB. Recovery of periodontopathogenic bacteria from embalmed human cadavers. Clin Anat 2005: 18: 64-67.

260. Wyss C. Dependence of proliferation of Bacteroides forsythus on exogenous $\mathrm{N}$-acetylmuramic acid. Infect Immun 1989: 57: 1757-1759.

261. Ximenez-Fyvie LA, Haffajee AD, Socransky SS. Comparison of the microbiota of supra- and subgingival plaque in health and periodontitis. J Clin Periodontol 2000: 27: 648-657.

262. Yang EY, Tanner AC, Milgrom P, Mokeem SA, Riedy CA, Spadafora AT, Page RC, Bruss J. Periodontal pathogen detection in gingiva/tooth and tongue flora samples from 18- to 48-month-old children and periodontal status of their mothers. Oral Microbiol Immunol 2002: 17: 55-59.

263. Yang HW, Huang YF, Chou MY. Occurrence of Porphyromonas gingivalis and Tannerella forsythensis in periodontally diseased and healthy subjects. J Periodontol 2004: 75: 1077-1083.

264. Yano-Higuchi K, Takamatsu N, He T, Umeda M, Ishikawa I. Prevalence of Bacteroides forsythus, Porphyromonas gingivalis and Actinobacillus actinomycetemcomitans in subgingival microflora of Japanese patients with adult and rapidly progressive periodontitis. J Clin Periodontol 2000: 27: 597-602.

265. Yoneda M, Hirofuji T, Anan H, Matsumoto A, Hamachi T, Nakayama K, Maeda K. Mixed infection of Porphyromonas gingivalis and Bacteroides forsythus in a murine abscess model: involvement of gingipains in a synergistic effect. $J$ Periodontal Res 2001: 36: 237-243.

266. Yue IC, Poff J, Cortes ME, Sinisterra RD, Faris CB, Hildgen P, Langer R, Shastri VP. A novel polymeric chlorhexidine delivery device for the treatment of periodontal disease. Biomaterials 2004: 25: 3743-3750.

267. Zambon JJ, Grossi SG, Machtei EE, Ho AW, Dunford R, Genco RJ. Cigarette smoking increases the risk for subgingival infection with periodontal pathogens. J Periodontol 1996: 67(10 Suppl.): 1050-1054. 